\title{
A brief history of ice core science over the last $50 \mathrm{yr}$
}

\author{
J. Jouzel ${ }^{1}$ \\ ${ }^{1}$ Laboratoire des Sciences de Climat et de l'Environnement/Institut Pierre Simon Laplace, CEA-CNRS-UVSQ - UMR8212, \\ CEA Saclay, L'Orme des Merisiers, Bt. 701, 91191 Gif/Yvette, Cedex, France \\ *Invited contribution by J. Jouzel, recipient of the EGS Milutin Milankovic Medal 1997.
}

Correspondence to: J. Jouzel (jean.jouzel@1sce.ipsl.fr)

Received: 30 April 2013 - Published in Clim. Past Discuss.: 3 July 2013

Revised: 24 September 2013 - Accepted: 30 September 2013 - Published: 6 November 2013

\begin{abstract}
For about $50 \mathrm{yr}$, ice cores have provided a wealth of information about past climatic and environmental changes. Ice cores from Greenland, Antarctica and other glacier-covered regions now encompass a variety of time scales. However, the longer time scales (e.g. at least back to the Last Glacial period) are covered by deep ice cores, the number of which is still very limited: seven from Greenland, with only one providing an undisturbed record of a part of the last interglacial period, and a dozen from Antarctica, with the longest record covering the last $800000 \mathrm{yr}$. This article aims to summarize this successful adventure initiated by a few pioneers and their teams and to review key scientific results by focusing on climate (in particular water isotopes) and climate-related (e.g. greenhouse gases) reconstructions. Future research is well taken into account by the four projects defined by IPICS. However, it remains a challenge to get an intact record of the Last Interglacial in Greenland and to extend the Antarctic record through the mid-Pleistocene transition, if possible back to $1.5 \mathrm{Ma}$.
\end{abstract}

\section{Introduction}

It was a great honour to be invited to give a lecture on the "History of ice core science" at the 2012 open Science Conference of IPICS, the International Partnerships in Ice Core Science. I did it as a scientist and not as an historian, using material from books such as "Frozen Annals" by Dansgaard (2004), the "Two-Mile Time Machine" by Alley (2000) and "White Planet" co-authored by Claude Lorius, Dominique Raynaud and myself, recently published by Princeton University Press (2013). My presentation was also based on a review article by Langway (2008) about "The history of early polar ice cores" and on many other scientific articles, reports and websites. I was also interested in looking at how ice core research, which for about fifty years has produced such a wealth of information about past changes in our climate and our environment, is perceived outside our scientific community; one well-documented example is given by Spencer Weart, an historian of science, who has written a book called "The discovery of global warming" (Weart, 2008, updated in 2013) with a chapter on Greenland ice drilling.

This review is written in the same spirit, and as a scientist I am probably unable to give an unbiased account of the history of ice core science, as a large part is also based on my own perception. I started environmental research fortyfive years ago and, thanks to Claude Lorius, had the opportunity to be involved in the first French deep drilling project, which in 1978 allowed us to recover a 905 m-deep ice core at the Dome C site on the Antarctic Plateau (Lorius et al., 1979). Except for Dye 3 (southern Greenland) and more recent projects such as WAISCORE (West Antarctica), I have been lucky to be part of or associated with major projects conducted since the eighties in Antarctica (Vostok, EPICA Dome $\mathrm{C}$ and EDML, Dome F, Law Dome, Talos Dome) and Greenland (GRIP, GISP2, North GRIP and NEEM); see Fig. 1 for the location of these Greenland and Antarctic sites. My participation in field work is more limited, with field seasons at GRIP, North GRIP and NEEM, but only a short visit in Antarctica.

This article deals both with the history of ice core drilling, including a brief account of ice cores recovered outside polar regions, and with ice core science. However, this would be too broad to cover all scientific aspects. Rather, I will focus on topics I am most familiar with, namely climate (in 

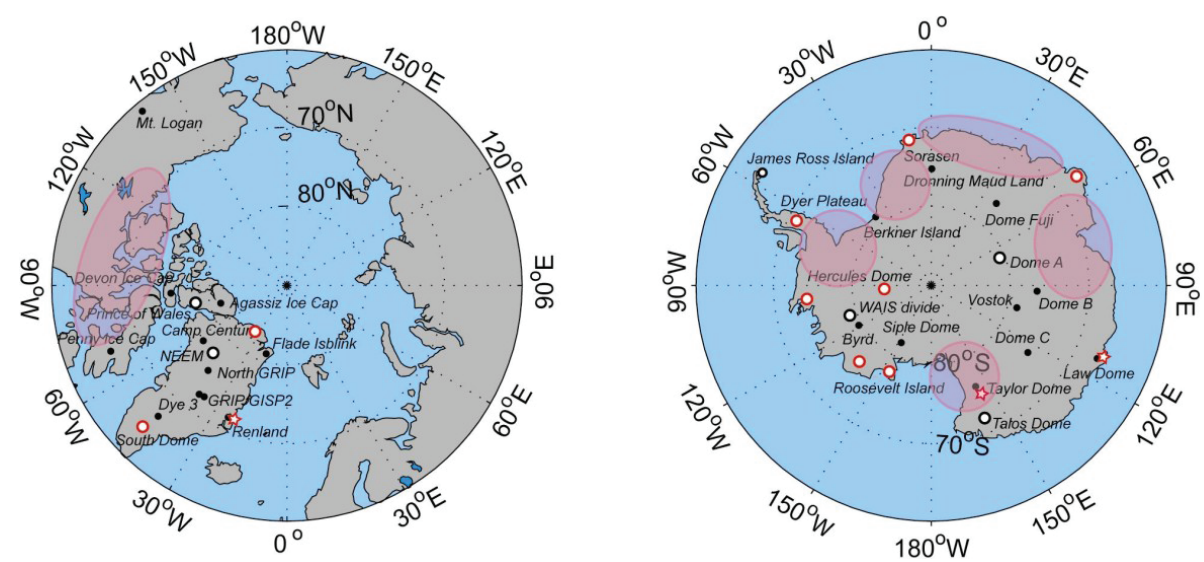

Fig. 1. Greenland and Antarctic deep drilling sites synthesised for the International Partnership for Ice Core Science (from http://www. pages-igbp.org/ipics/).

particular water isotopes) or climate-related (e.g. greenhouse gases) reconstructions as well as dating issues. Aspects dealing with the chemical composition of snow and ice, with the information that can be derived on past changes in atmospheric chemistry and biogeochemical cycles, with the fallout of cosmogenic isotopes, with the physics of ice, and with the modelling of ice flow and ice sheets, will not be covered.

\section{Ice core drilling: from Camp Century to the WAIS divide ice core}

As reviewed by Langway (2008), the first attempt to probe the interior of an ice sheet was conducted by Sorge (1935) from the study of a $15 \mathrm{~m}$-deep pit recovered at Station Eismitte (Greenland). The first ice cores were obtained about twenty years later by three separate international research teams (Langway, 2008): the Norwegian-British-Swedish Antarctic Expedition on the Queen Maud Land - now Dronning Maud Land - coast (Swithinbank, 1957; Schytt, 1958), the Juneau Ice Field Research Project in Alaska (Miller, 1954) and the Expeditions Polaires Françaises in central Greenland (Heuberger, 1954). These ice cores drilled in the early fifties were about $100 \mathrm{~m}$ deep, with generally low quality of ice recovery preventing detailed analytical studies (Langway Jr., 1958), and one can mark the 1957-1958 International Geophysical Year (IGY) as the starting point of ice core research. One of the IGY's priorities was deep core drilling into polar ice sheets for scientific purposes. Five nations were particularly active in the early period of deep drilling projects in polar regions - the sixties and seventies - the USA, the Soviet Union, Denmark, Switzerland and France.

Under the leadership of Henri Bader and then of Chet Langway, US teams were very active thanks to two US Army Corps of Engineers research laboratories: the Snow, Ice and Permafrost Research Establishment (SIPRE) merged in 1961 with another US Army research laboratory to form the (current) Cold Regions Research and Engineering Laboratory (CRREL). In Greenland, two cores were drilled at Site 2 in 1956 (305 m) and 1957 (411 m), closely followed by two cores in Antarctica, at Byrd Station in 1957/1958 (309 m), and at Little America V, on the Ross Ice Shelf, in 1958/1959 $(264 \mathrm{~m})$. The drilling operation moved in Camp Century in northwestern Greenland in the fall of 1960 and it then took a strenuous six-year field effort to recover the first ever continuous ice core to the bedrock depth, $1388 \mathrm{~m}$ long (Hansen and Langway, 1966; Langway, 2008). The drillers of CRREL went on to Antarctica at Byrd Station, a site in West Antarctica chosen (as Camp Century) because of its accessibility. The drilling was a success, reaching $2164 \mathrm{~m}$ in 1968, but unfortunately the drill remained at the bottom of the hole and US drillers had to wait until 1993 to again celebrate the success of a deep drilling.

Over this period, international partnership was established between CRREL and other US teams with teams from the University of Copenhagen and Bern led respectively by Willi Dansgaard and Hans Oeschger. Dansgaard was a pioneer in the establishment of the close link between the isotopic composition of polar snow $\left(\delta^{18} \mathrm{O}\right.$ and $\left.\delta \mathrm{D}\right)$ and the temperature at the precipitation site (Dansgaard, 1953, 1964). With his Copenhagen team, he was the first to recover continuous isotopic profiles along deep ice cores (Dansgaard et al., 1969; Johnsen et al., 1972); such an isotopic approach was also developed in the US, largely on the initiative of Sam Epstein (Epstein et al., 1970). The initial interest of Oeschger, a specialist in low-level carbon 14 dating, was about radiocarbon dating of ice (Oeschger et al., 1966, 1967). Following the success of the Camp Century and Byrd drillings, this collaboration between the USA, Denmark and Switzerland developed the concept of a Greenland Ice Sheet Project (GISP) in the early seventies. After the loss of the drill at Byrd, the Copenhagen team took over and, under the direction of Niels Gunderstrup and Sigfus Johnsen, developed their own drill, 
known as Istuk. For logistical reasons the Dye 3 site in southern Greenland was chosen for this new drilling project; after three seasons (1979-1981) the bedrock was reached at a depth of $2038 \mathrm{~m}$ (Dansgaard et al., 1982).

Soviet and Russian activities started in 1955 with drilling in the Arctic and non-polar regions, and in 1956 in Antarctica with a $377 \mathrm{~m}$ deep core drilled near Mirny in 1957. The first attempt at deep-hole drilling at Vostok was started in April 1970, with a depth of $506.9 \mathrm{~m}$ reached by September 1970 (Ueda and Talalay, 2007 and references therein). At this site, the drilling activity, under the leadership of Ye. S. Korotkevich, culminated in the recovery of the deepest core ever obtained, reaching a depth of $3623 \mathrm{~m}$ (Petit et al., 1999) in a project joined in the eighties by French teams led by Claude Lorius and later by US teams with the strong involvement of Michael Bender (now at Princeton University). This Vostok drilling was recently extended down to the interface with Lake Vostok at a depth of $3769 \mathrm{~m}$ in February 2012 (V. Lipenkov, personal communication, 2012). As fully discussed below, in the eighties the Vostok ice core was the first ice core to cover a full glacial-interglacial cycle.

French drilling activities started in Antarctica with drilling undertaken in the sixties and seventies in the coastal regions at proximity of French base Dumont d'Urville (Adelie Land, East Antarctica). The French team then carried out a $905 \mathrm{~m}$ deep drilling at the inland site of Dome C (Lorius et al., 1979), at a location - which, unlike Camp Century, Byrd and Vostok - was deliberately chosen on a dome where the interpretation of ice core data is in principle easier because ice at depth is formed from snow which has fallen on the site itself. Involving teams from Grenoble, Saclay and Orsay, this core was the basis for new investigations such as measurements of beryllium 10, a cosmogenic isotope (Raisbeck et al., 1981), of carbon dioxide (Delmas et al., 1980), of $\delta \mathrm{D}$ and $\delta^{18} \mathrm{O}$ (Jouzel et al., 1982), and of the oxygen 18 of $\mathrm{O}_{2}$ (Bender et al., 1985).

Two other nations, Australia and Canada, started drilling in polar regions in the sixties and seventies. The Australian National Antarctic Research Expeditions (ANARE) focused on Law Dome, a small ice sheet located at the edge of the Indian Ocean sector of East Antarctica, where a $382 \mathrm{~m}$ ice core was drilled in 1969 and to $477 \mathrm{~m}$ in 1977 (Hamley et al., 1986); in the nineties, a new drilling was performed at a different site (Dome Summit South), with a depth of $553 \mathrm{~m}$ reached in 1991-1992 and completion down to the bedrock in February 1993 (Morgan et al., 1997). Stan Paterson and Roy Koerner played a key role in the development of Canadian activities in the Arctic, where the first ice cores were recovered down to the bedrock on Devon Ice Cap in the seventies (Paterson et al., 1977; Koerner, 1977) and later on Agassiz Ice Field, Penny Ice Cap and and Prince of Wales Ice Sheet (Fisher et al., 2011).

Focusing on deep drilling that we define as extending beyond the Last Glacial Maximum, $20000 \mathrm{yr}$ ago (hereafter LGM), we now briefly describe the projects which have been undertaken in Greenland and Antarctica over the last thirty years. We also mention shorter cores drilled outside these regions.

\subsection{Deep drilling in Greenland}

Both the Camp Century and the Dye 3 drilling sites (Fig. 1) were chosen for their accessibility from Thule (Pituffik) to the northwest and Sondrestrom Air Base (Søndre Strømfjord/Kangerlussuaq) to the southwest, and for existing infrastructures. Camp Century was drilled as part of the Camp Century cold war "city under the ice" experiment and Dye3 was an American cold war Distant Early Warning radar base on the ice sheet. Both cores reach the Last Glacial period, with the discovery of a succession of abrupt climate changes, but they do not provide reliable information about the Last Interglacial. Indeed, Dansgaard and his GISP colleagues were persuaded of the interest of drilling in the centre of Greenland to cover this key period - an objective reached in Antarctica in the mid-eighties thanks to the Vostok operation (Lorius et al., 1985). However, it was not simple to convince the US National Science Foundation (NSF) of the merit of such a project.

Dansgaard found an effective ally in Wally Broecker, a geochemist and oceanographer at Columbia University (New York), who like Hans Oeschger was fascinated by the connection between the rapid variations discovered at Dye 3 and the potential changes in the ocean current in the North Atlantic (Oeschger, 1985; Oeschger et al., 1984; Broecker et al., 1985). In January 1987, Broecker, who was in favour of an international project between US and European teams, organised a meeting involving scientists from both sides. At this Boston meeting, Dansgaard pledged for the drilling of two cores, one European, the other American. This proposition was collectively adopted, as the expected results were of such importance that it appeared indispensable to confirm them in parallel on a second drilling site. The Europeans chose the highest point for their GRIP (GReenland Ice core Project) project, the Americans a site $28 \mathrm{~km}$ farther west (GISP 2).

At the European site, the Eurocore project started by the Eurocore programme involving Denmark, France and Switzerland, launched in 1989 with the strong support of the European Communities, was dedicated to the study of the last $1000 \mathrm{yr}$ from a $300 \mathrm{~m}$ core. Under the auspices of the European Science Foundation (ESF), five other countries Germany, the UK, Belgium, Iceland and Italy - joined to launch GRIP in June 1990. One of the novelties was the building of an expanded "science trench" (a concept already used at Camp Century, Byrd and Dye 3) with, in addition to the preparation of the samples, measurements of some ice properties; this strategy has been adopted for other Greenland sites (Fig. 3) and for EPICA Dome C. The drilling was carried out over three summers, reaching $3028.8 \mathrm{~m}$ on 12 July 1992 (Dansgaard et al., 1993) using Istuk. The 


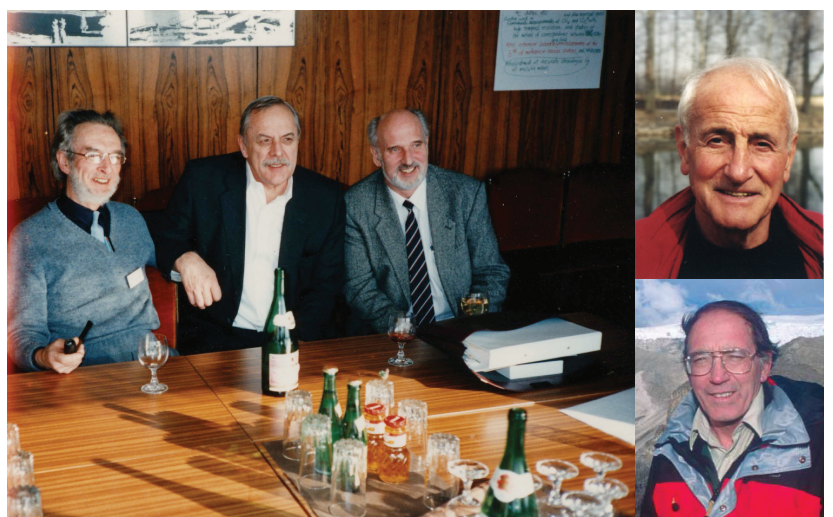

Fig. 2. Some pioneers of ice core research: left panel: Willi Dansgaard, Chet Langway and Hans Oeschger (from left to right); upper right panel: Claude Lorius; lower right panel: Lonnie Thompson.

American team had less luck: the drill was entirely satisfactory but the cable proved problematic. After three years of drilling, a new cable had to be used, postponing the success of the drilling by one season (bottom reached in July 1993 at $3054 \mathrm{~m})$.

Due to disturbances related to the proximity of the bedrock, neither of these two cores provided reliable climatic information beyond $100000 \mathrm{yr}$ or so (Grootes et al., 1993; Taylor et al., 1993); this was disappointing for all the teams involved in either logistic, drilling or scientific activities. As this could be linked to the hilly subglacial relief in this area of central Greenland, there was hope that a site with a flatter relief would allow one to overcome this problem. A zone located $200 \mathrm{~km}$ north of GRIP appeared a priori favorable; in 1995, the Copenhagen team, under the leadership of first Claus Hammer and later Dorthe Dahl-Jensen, launched the North GRIP international project joined by colleagues from Belgium, France, Germany, Iceland, Japan, Sweden, Switzerland and the USA. The drilling began successfully in 1996, but the drill (an expanded version of the Hans Tausen drill developed by the Copenhagen team and tested in 1995 at Hans Tausen Glacier with French participation) was blocked the following season at a depth of $\sim 1400 \mathrm{~m}$. In 1999, the international team decided to start again from the surface, and a depth of $2931 \mathrm{~m}$ was reached in two seasons, but the drilling was subsequently greatly slowed down because of "warm" ice due to high geothermal flux in this area. The drilling ended in 2003 at a depth of $3085 \mathrm{~m}$ in a subglacial river, the presence of liquid water in fact reducing the risk of ice flow perturbation as observed at GRIP and GISP2. As a result, North GRIP provides undisturbed climatic time series over the last $123000 \mathrm{yr}$, covering a significant part of the last interglacial period (North GRIP community, 2004).

Further extending the Greenland record was the objective of a drilling undertaken farther north, between North GRIP and Camp Century, at the NEEM (North Greenland Eemian ice drilling) site. New teams (Canadian, Chinese and Korean)

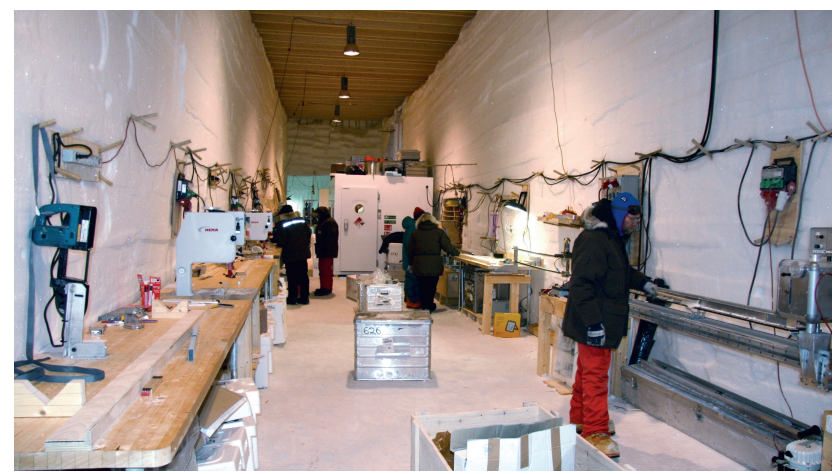

Fig. 3. The science trench at NEEM.

joined the project which reached the bedrock at a depth of $2537 \mathrm{~m}$ in July 2010. As for GRIP and GISP2, the bottom part is perturbed by ice flow below $\sim 2.2 \mathrm{~km}$. However, available data shows that a correct time sequence can be reconstructed back to $128500 \mathrm{yr}$ ago, thus providing records over a large part of the Eemian (NEEM Community Members, 2013).

\subsection{Deep drillings in Antarctica}

In the seventies, the high ground in paleoclimate studies was indisputably held by paleoceanographers, who were able to produce climatic time series covering several climatic cycles. These long records allowed Hays et al. (1976) to establish the validity of the Milankovitch theory of ice ages. To make a significant contribution, glaciologists, with no ice core extending beyond the last glacial period, must necessarily go back in time. The drilling team of the Leningrad Mining Institute, which alternated the use of thermal and electromechanical drills (Ueda and Talalay, 2007), was the first to recover ice from the previous glacial period, $150000 \mathrm{yr}$ ago (Lorius et al., 1985), thanks to very low accumulation.

At this site, where drilling was carried out throughout the year despite winter temperatures below $-70^{\circ} \mathrm{C}$, the second core was completed at $950 \mathrm{~m}$ depth in 1972, starting from a deviation from the first hole. In case of difficulty, this technique, developed by the Soviet drillers and often used during the Vostok project (Fig. 4), allows one to continue drilling without starting from the surface again. Overall, it took $12 \mathrm{yr}$ between the first ice core (1970) and the recovery of previous interglacial ice on core $3 \mathrm{G}$, the third core, which reached a depth of $2083 \mathrm{~m}$ on 11 April 1982 (Ueda and Talalay, 2007). The next day the electric generator used for the camp caught fire and the operations were suspended because the generator for the drillers was indispensable for ensuring the survival of the camp.

This fire did not alter the enthusiasm of the Soviet drillers. In 1984, they undertook the drilling of core $4 \mathrm{G}$ from the surface. In parallel, they attempted a deviation at the bottom of $3 \mathrm{G}$ which provided an extension down to $2200 \mathrm{~m}$, a 


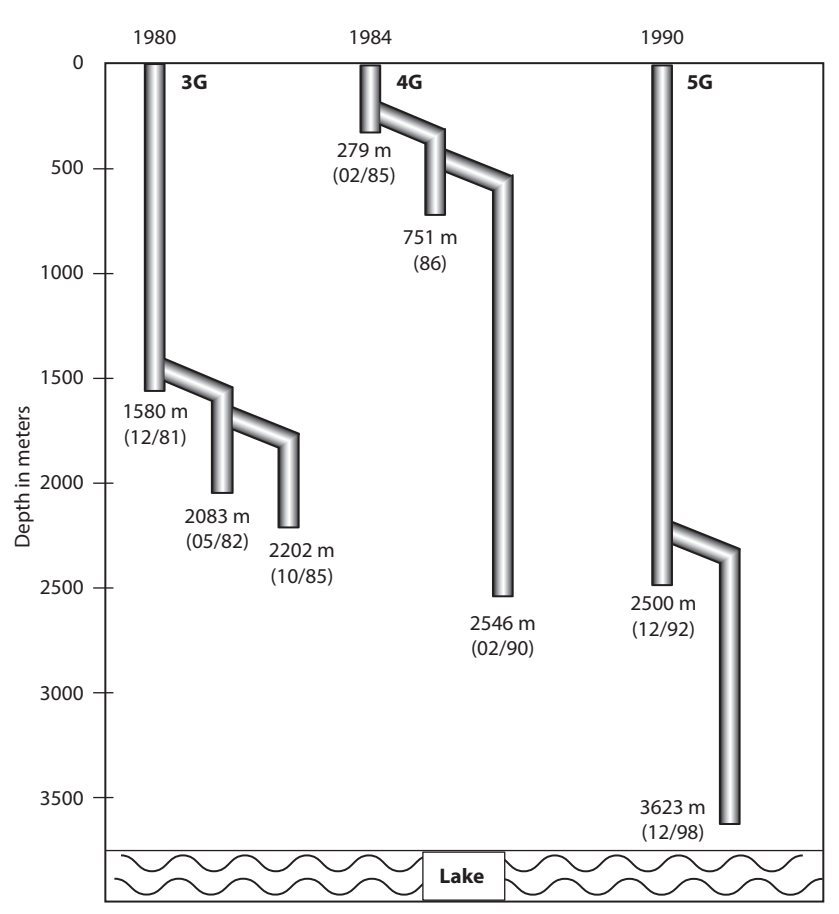

Fig. 4. Deep drilling at the Vostok site.

depth at which the drill was blocked and drilling in this hole definitely abandoned in November 1985. Drilling of 4G continued relatively slowly but without problems until February 1990. Again, the drill was blocked, at a deeper depth $(2546 \mathrm{~m})$ but still in the previous glacial period, $\sim 220000 \mathrm{yr}$ ago (Jouzel et al., 1993). During the eighties, Soviet drillers recovered two other cores (Ueda and Talalay, 2007): a $850 \mathrm{~m}$ ice core extending into the last transition at Komsomolskaïa in 1983 (Nikolaiev et al., 1988; Ciais et al., 1992) and, in 1988 , a $780 \mathrm{~m}$ core covering the last $30000 \mathrm{yr}$ at Dome B (Jouzel et al., 1995).

The project might well have been abandoned, but thanks to the Russian drillers, to the support of the French and US teams, and to the heavy involvement of two scientists, Volodya Lipenkov and Jean-Robert Petit, the project went on even if it was necessary to start again from the surface at the end of 1990. A depth of $2755 \mathrm{~m}$ was reached in January 1994 and the core then covered two full climatic cycles (Waelbroeck et al., 1995; Jouzel et al., 1996). Then a depth of $3350 \mathrm{~m}$ was reached in January 1996, with an estimated age of $420000 \mathrm{yr}$ at $3310 \mathrm{~m}$ (Petit et al., 1999), a depth below which mixing of ice makes the climatic interpretation of the records more difficult (Raynaud et al., 2005). Close to thirty years after the operation began, core drilling was stopped in December 1998 at around $120 \mathrm{~m}$ above the interface with Lake Vostok. As mentioned, drilling operations have resumed and this interface was reached in February 2012.

The success of GRIP has created a spirit of collaboration between all European partners involved, and it is natural that they built a European Project for Ice Coring in Antarctica just after this success. The GRIP collaboration was extended to teams from the Netherlands, Norway and Sweden, and to the Russian team of V. Lipenkov. The idea was for two complementary sites in East Antarctica, one at Dome $\mathrm{C}$ in a low accumulation area with a previous drilling operation, and one to be located in the Atlantic sector, which was then completely unexplored, so as to enable an optimal comparison with the records in Greenland. An EPICA electromechanical drill was developed based on the Danish North GRIP - Hans Tausen design, and the project was launched in 1995 under my responsibility, with Bernhard Stauffer as chair of the science group; these responsibilities were taken over by Heinz Miller and Eric Wolff in 2002. The Dome C drilling, which benefited from the logistical support of France and Italy, began in November 1997, but the drill was stuck at a depth of $780 \mathrm{~m}$ after two seasons. The operations very successfully resumed at the end of 2000, and a depth of $2871 \mathrm{~m}$ was reached in two seasons; at this depth the retrieved climate record was already older than at Vostok (more than $500000 \mathrm{yr}$ old). The drilling conditions then became increasingly difficult; the bedrock $(3260 \mathrm{~m})$ was reached in January 2005, with the longest exploitable records covering slightly more than $800000 \mathrm{yr}$ (EPICA Community Members, 2004; Jouzel et al., 2007a). The second EPICA drilling logistically supported by Germany (Kohnen Station in the Dronning Maud Land sector) began in 2001 and, using the North GRIP drill, reached the bedrock $(2760 \mathrm{~m})$ during the 2005-2006 field season without noticeable difficulties. It extends, at least, in the previous glacial period (EPICA Community Members, 2006).

Another drilling project was carried out in the nineties by the Japanese team of NIPR (National Institute of Polar Research) then under the responsibility of Okitsugu Watanabe. As at Vostok, the drilling team was operating throughout the year with a drill designed for this drilling. At the chosen site of Dome F, a depth of $2503 \mathrm{~m}$ (ice $\sim 330000 \mathrm{yr}$ old) was reached in two years, 1995 and 1996 (Watanabe et al., 2003). Due to the drill loss, a new drilling had to be started from the surface. The bedrock $(3035 \mathrm{~m})$ was reached at the beginning of 2006; this successful operation provides ice records spanning the last $720000 \mathrm{yr}$ (Kawamura et al., 2012). The interest of China in ice core drilling is more recent: in 2004/2005, a $110 \mathrm{~m}$-long ice core was recovered at Dome Argus, the summit of the East Antarctic plateau, by the Chinese National Antarctic Research Expedition (Xiao et al., 2008).

During this period, US logistical support was primarily devoted to the reconstruction of the permanent base on the South Pole and to the Icecube experiment dedicated to the detection of neutrinos. US scientists concentrated on sites easily accessible from McMurdo with two drillings completed respectively in 1994 and 1999, a $554 \mathrm{~m}$ drilled at Taylor Dome using the PICO drill (Grootes et al., 1994; Steig et al., 1998) and a $1004 \mathrm{~m}$ core retrieved at Siple Dome using the GISP-2 drill (Gow and Engelhardt, 2000; Taylor et al., 2004). Both cores gave access to ice from the last glacial period. A 
more ambitious drilling project, WAIS for West Antarctic Ice Sheet, has recently been carried out (between 2008 and 2011) using a new DISC (Deep Ice Sheet Coring) drill, $160 \mathrm{~km}$ from the location of the Byrd ice core. The bedrock has been reached at a depth of $3405 \mathrm{~m}$; due to the high accumulation, the core does not extend beyond the last $62000 \mathrm{yr}$, but has the advantage of providing very high resolution records (WAIS, 2013).

Other teams have chosen one of the small and more easily accessible domes in the coastal regions. We have already cited the Australian drilling intiated in the late sixties at Law Dome (Hamley et al., 1986; Morgan et al., 1997). More recently, successful drilling operations have been conducted at Berkner Island (Mulvaney et al., 2007) and Talos Dome (Stenni et al., 2011) as collaborative projects under the respective leadership of UK and Italy. Talos Dome covers a full glacial-interglacial cycle, while the Law Dome and Berkner Island cores extend into the last glacial period. This is also the case for a $364 \mathrm{~m}$ core drilled by a UK-French team on James Ross Island (Mulvaney et al., 2012), where two shorter cores were drilled in the eighties in collaboration between Argentinian and French teams (Aristarain et al., 1986, 1990). Ice from glacial periods is also accessible from near-coastal sites (Yao et al., 1990) or from "horizontal" ice cores allowing one to retrieve old ice in the ice margins (Reeh et al., 2002; Dunbar et al., 2008).

\subsection{Drilling in the Andes and the Himalaya}

Lonnie Thompson (Ohio State University) was the first scientist to launch extensive ice core drilling and to believe in the scientific value of cores extracted from tropical glaciers, some of them being at risk of disappearing under the effect of global warming. With his team, he was able to circumvent the difficulties of drilling above $6000 \mathrm{~m}$ by developing light drills that run on solar energy, and means to bring the ice back down as quickly as possible to avoid melting. Several tropical ice cores have been obtained that reached back the Last Glacial period, either in the Himalayas, Dunde (Thompson et al., 1989) and Guliya (Thompson et al., 1997), or in the Andes, Huascaran (Thompson et al., 1995) and Sajama (Thompson et al., 1998). Other teams have followed on this pioneering work both in the Andes (Ramirez et al., 2003) and the Himalayas, now referred to as the Third Pole (Yao et al., 2012). Although some of these cores extend back to the Last Glacial period, their main interest is that they are excellent archives of past El Niños (Andean glaciers) and of past monsoons (Himalayan glaciers). A presentation of associated scientific results is beyond the scope of this article, as well as a comprehensive review of ice cores drilled in glaciers from non-polar regions (Alps, Kilimanjaro, Mongolia, Russia, Canada etc.) and in the Arctic.

\section{Deep ice cores: what do we learn about past climate changes?}

In the line of the seminal paper "Stable isotopes in precipitation" published by Dansgaard (1964), climate reconstruction from ice cores has long been based on interpreting $\delta^{18} \mathrm{O}$ (oxygen 18) or $\delta \mathrm{D}$ (deuterium) profiles measured along ice cores. This approach is still extensively used, but alternative methods such as paleothermometry and the use of the isotopic composition of permanent gases $\left(\delta^{15} \mathrm{~N}\right.$ and $\left.\delta^{40} \mathrm{Ar}\right)$ have been developed since the nineties. Before examining the information obtained by these complementary approaches, we briefly mention the various methods used to date ice cores as summarized in Jouzel and Masson-Delmotte (2010a). Based on a recent review (Jouzel et al., 2013), we then briefly discuss how isotopic models are useful for interpreting isotopic profiles measured along ice cores, and mention the interest in combining measurements of $\delta \mathrm{D}, \delta^{18} \mathrm{O}$ and, as recently developed, of $\delta^{17} \mathrm{O}$.

\subsection{Establishing ice core chronologies}

Complementary methods are used to establish ice core chronologies. They fall into four categories: (1) layer counting, (2) glaciological modelling, (3) use of time markers and correlation with other dated time series, and (4) comparison with insolation changes (i.e. orbital tuning). Layer counting based on a multi-parametric approach is extensively used for Greenland cores (Hammer et al., 1986; Johnsen et al., 1992; Meese et al., 1997; Alley et al., 1997; Rasmussen et al., 2006; Svensson et al., 2008) and for high-accumulation Antarctic sites. It is not feasible in low-accumulation areas such as central Antarctica, where other approaches must be employed. For example, the Vostok core has been initially dated combining an ice flow and an accumulation model assuming a link between accumulation and temperature (Petit et al., 1999). Orbital information contained in various time series such as methane (Ruddiman and Raymo, 2003), $\delta^{18} \mathrm{O}$ of atmospheric oxygen (Jouzel et al., 1996, 2002; Petit et al., 1999; Shackleton, 2000; Dreyfus et al., 2007; Bazin et al., 2013), $\mathrm{N}_{2}-\mathrm{O}_{2}$ ratio in air bubbles (Bender, 2002; Kawamura et al., 2007; Suwa and Bender, 2008; Landais et al., 2012) and total air content (Raynaud et al., 2007; Lipenkov et al., 2011) are also used. Additional dating information, either relative or absolute, is also obtained from comparison with other paleorecords (Raisbeck et al., 2006, 2007; Waelbroeck et al., 2008). The idea of an optimal use of the different sources of chronological information and of the various glaciological constraints has been exploited through an inverse modelling approach (Parrenin et al., 2001, 2004 and references therein). Inverse modelling is now of current use to provide a consistent dating of Greenland Antarctic ice cores (Lemieux-Dudon et al., 2010; Bazin et al., 2013).

At a given depth, the age of the gas is younger than the age of the ice, due to the fact that air bubbles are trapped 


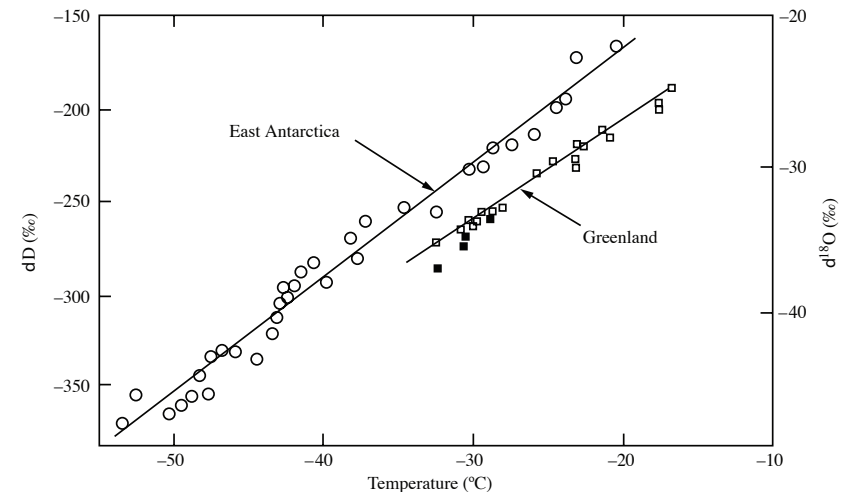

Fig. 5. Isotope content of snow versus local temperature (annual average). Antarctic data $(\delta \mathrm{D}$, left scale) are from Lorius and Merlivat (1977) and Greenland data $\left(\delta^{18} \mathrm{O}\right.$, right scale) are from Johnsen et al. (1989).

when firn closes off at depth. The ice age - gas age difference can be estimated as a function of temperature and accumulation through firnification models (Barnola et al., 1991; Arnaud et al., 2000). The application of such models is however subject to discussion (Landais et al., 2006), and clearly contradicted by independent estimates based on alternative methods (Parrenin et al., 2013).

\subsection{Water isotopes as indicators of past temperatures}

The isotopic change measured between the LGM and the more recent period is relatively similar for ice cores from the central regions of Antarctica and Greenland, with a range of $\delta^{18} \mathrm{O}$ variations around $5 \%$. This range, also observed for some near-coastal sites, is larger for sites affected by significant altitude changes for LGM ice as, for example, observed at Camp Century (Dansgaard et al., 1969; Raynaud and Lorius, 1973; Vinther et al., 2009).

The interpretation of these isotopic data is largely based on their present-day distribution characterized by a linear relationship between their annual values and the mean annual precipitation site temperature, particularly well obeyed over Greenland and Antarctica (Fig. 5). While Dansgaard and his team opted for a qualitative interpretation of $\delta^{18} \mathrm{O}$ profiles, Lorius and colleagues proposed quantitative estimates of associated temperature changes based on the use of this observed present-day spatial slope. This approach was first used for the old Dome C core (Lorius et al., 1979). Corrections for changes in the isotopic composition of oceanic waters, in the altitude of the ice sheet and, if necessary, for the upstream origin of the ice (EPICA Community Members, 2006), are applied. With this interpretation, the four long East Antarctic isotopic records (Vostok, Dome F, EPICA Dome C and EDML) show a consistent range of $\sim 8$ to $10^{\circ} \mathrm{C}$ between the LGM and present-day surface temperatures (Fig. 6).

Over a longer timescale, the minimum isotopic values reached during the coldest parts of the glacial periods are

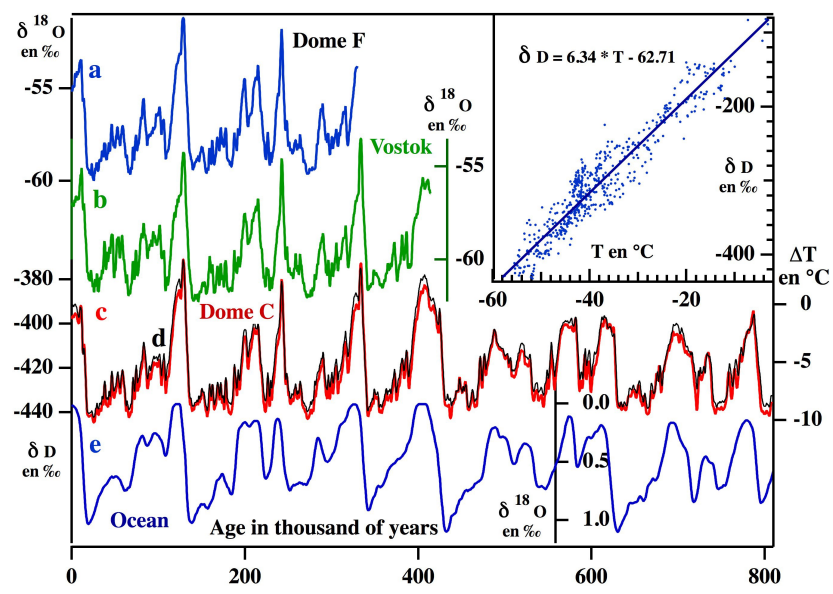

Fig. 6. Stable isotope records from deep Antarctic ice cores: Dome F (Watanabe et al., 2003), Vostok (Petit et al., 1999) and Dome C (Jouzel et al., 2007a), in addition to the Dome C temperature (red curve, temperature scale on the right) estimated using the conventional approach (based on the use of the spatial slope, see insert adapted from Masson-Delmotte et al., 2008) as a surrogate of the temporal slope. The oceanic record adapted from Lisiecki and Raymo (2005) is used as a proxy of sea-level change.

remarkably similar. Instead, high values can be more variable from one interglacial to the next; for example, during the Last Interglacial, $\delta^{18} \mathrm{O}$ was higher than during the recent Holocene (Masson-Delmotte et al., 2011), which is also true for the three previous interglacials (Petit et al., 1999; Watanabe et al., 2003; EPICA community Members, 2004; Jouzel et al., 2007a). The EPICA Dome C record illustrates a change in pacing at the time of the Mid-Brunhes event about $430 \mathrm{kyr}$ BP, with lower glacial-interglacial isotopic changes before this event (which is followed by an exceptional $\sim 28$ ka-long interglacial; EPICA Community Members, 2004).

The most important characteristic of the Greenland records deals with the existence of rapid climatic changes during the last glacial period and the last transition (Fig. 7). These "Dansgaard-Oeschger" events (named by Wally Broecker) were discovered in the Camp Century and Dye 3 Greenland cores (Dansgaard et al., 1982, 1984). Rapid isotopic changes, often more than half of those corresponding to the glacial-interglacial difference and taking place in a few decades or even less (Steffensen et al., 2008), are followed by a slower cooling and a generally rapid return to glacial conditions. These isotopic events are accompanied by rapid changes in snow accumulation (Alley et al., 1993) and in dust fallout (Taylor et al., 1993). The existence and characteristics of these events were fully confirmed at GRIP (Dansgaard et al., 1993) and GISP2 (Grootes et al., 1993), and more recently at North GRIP (North GRIP Community Members, 2004) and NEEM (Neem Community, 2013). For Camp Century (Dansgaard et al., 1969) and Dye 3 (Dansgaard et al., 


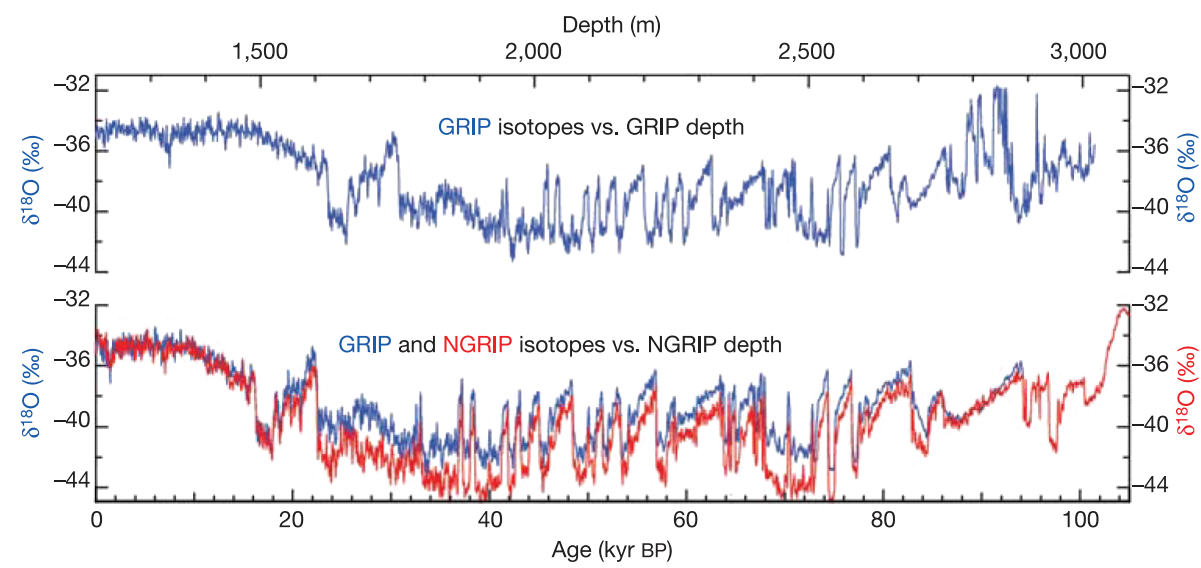

Fig. 7. The GRIP (a, blue) and NGRIP (b, red) oxygen isotopic profiles with respect to depth. For comparison, the GRIP record (blue) has been plotted on the NGRIP depth scale using the rapid transitions as tie points (adapted from North GReenland Ice core Project members, 2004).

1982), the $\delta^{18} \mathrm{O}$ profile was used as a proxy of temperature change, but only on a qualitative basis (Johnsen et al., 1972). Instead, the conventional approach was applied for GRIP (Johnsen et al., 1992) and GISP 2 (Grootes et al., 1993), leading to estimates of the LGM cooling of $\sim 10$ to $13^{\circ} \mathrm{C}$.

\subsection{Alternative estimates of temperature changes in Greenland and Antarctica}

It appeared that this conventional approach significantly underestimates Greenland past temperature changes. This was somewhat a surprise in our community, when the interpretation of the borehole temperature profile clearly showed that the temperature increase from glacial maximum to Holocene was higher than $20^{\circ} \mathrm{C}$, and up to $25^{\circ} \mathrm{C}$ at Summit (Cuffey et al., 1995; Johnsen et al., 1995; Dahl-Jensen et al., 1998), about two times higher than the conventional approach factor. Indeed, such factors as the evaporative origin and the seasonality of precipitation can also affect $\delta \mathrm{D}$ and $\delta^{18} \mathrm{O}$. If these factors change markedly under different climates, the spatial slope can no longer be taken as a reliable surrogate of the temporal slope for interpreting the isotopic signal. This is the case for Greenland, where the seasonality of the precipitation is substantially increased during the LGM (Werner et al., 2000), unlike for Antarctica (Krinner et al., 1997).

A new method was then developed by Severinghaus and colleagues based on the fact that air composition is very slightly modified by physical processes, among them the gravitational and thermal fractionation. In the case of a rapid temperature change, these processes cause a detectable anomaly in the isotopic composition of nitrogen and argon, which allows us to infer its size. This method was applied to the rapid changes associated with the end of the Younger-Dryas (Severinghaus et al., 1996, 1998) and with the abrupt warming that led to the Bølling (Severinghaus and Brook, 1999), providing higher warming estimates ( up to a factor of 2) than derived from ice $\delta^{18} \mathrm{O}$. The abrupt warming that marked the start of the numerous DO events during the Last Glacial period are also larger than initially thought (Lang et al., 1999; Schwander et al., 1997; Landais et al., 2004a,b; Huber et al., 2006; Landais, 2011; Capron et al., 2010). To sum up, all the results derived either from borehole paleothermometry or from isotopic anomalies significantly underestimate temperature changes in central Greenland, thus seriously challenging the conventional isotopic approach. Fractionation processes occurring during firnification are now studied for other noble gases: neon, kryton and xenon (Severinghaus and Battle, 2006); due to the dependence of gas solubility on temperature, the krypton-nitrogen ratio has been used to reconstruct past mean ocean temperature (Headly and Severinghaus, 2007).

In Antarctica, both paleothermometry and the use of nitrogen and argon isotopes pose some problems due to the low accumulation and to the fact that Antarctica did not experience abrupt temperature changes. Thus, there is no perfect alternative to calibrating the isotopic paleothermometer there. Still, there are useful arguments coming from the isotopic composition of the air bubbles (Caillon et al., 2001), from constraints with respect to ice core chronologies (Parrenin et al., 2001, 2007; Blunier et al., 2004) and from paleothermometry (Salamatin et al., 1998). As reviewed by Jouzel et al. (2003), they converge towards the idea that the observed present-day spatial slope can be used to interpret Antarctic isotopic profiles with however a slight underestimation, of the order of $\sim 10 \%$, of temperature changes.

A noticeable feature of the distribution of water isotopes, which at the surface are affected by wind scouring (Fisher et al., 1983), is the smoothing due to the diffusion in firn and ice (Johnsen, 1977) which affects the seasonal cycle and can also erase sub-millennial variations in old ice (Pol et al., 2010). The difference in firn diffusion of water isotopes (Johnsen et al., 2000) offers the possibility to estimate past 

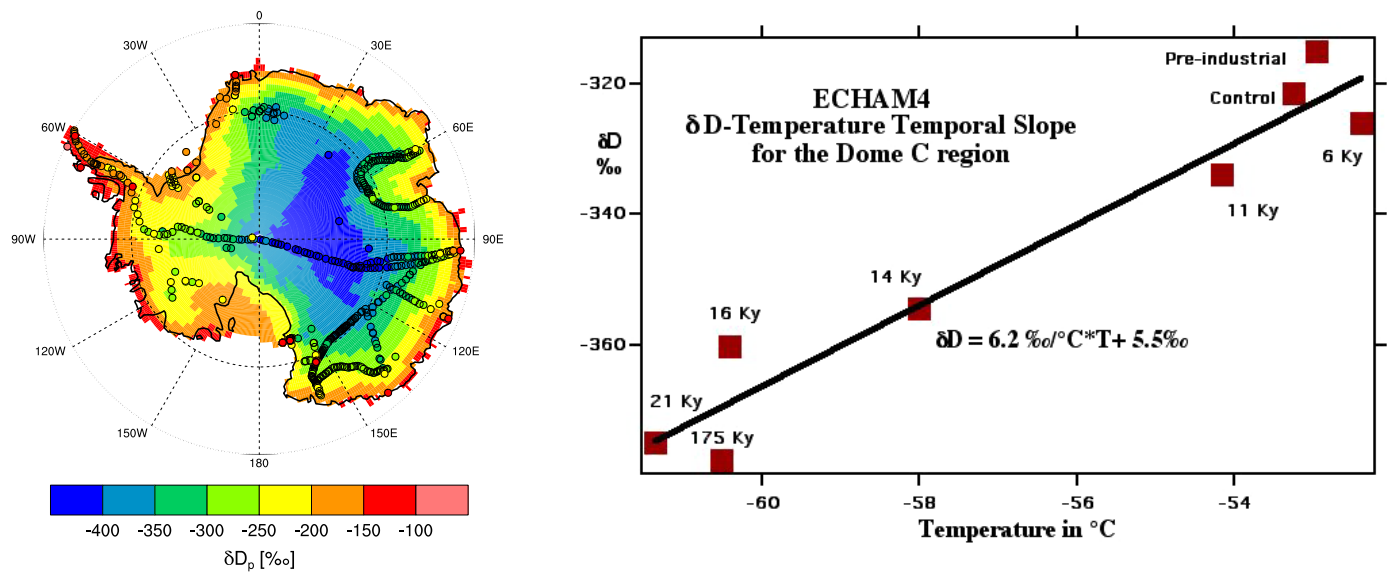

Fig. 8. Left panel: observed (coloured circles from a compilation by Masson-Delmotte et al., 2008) and simulated (ECHAM5-wiso with fine spatial T159L31) annual mean HDO values in precipitation ( $\delta$ Dp) for Antarctica (after Werner et al., 2011). Right panel: the temporal slope as derived from ECHAM 5 IGCM for the Dome C region (Jouzel et al., 2007b).

temperature changes from very detailed $\delta \mathrm{D}$ and $\delta^{18} \mathrm{O}$ profiles in ice cores (Simonsen et al., 2011). Co-isotopic measurements $\left(\delta \mathrm{D}\right.$ and $\delta^{18} \mathrm{O}$ ) have also been applied to study basal ice as a result of the fractionation processes taking place during melting/refreezing processes (Jouzel and Souchez, 1982; Souchez and Jouzel, 1984; Jouzel et al., 1999).

At last, climate information can be retrieved from the meltfeature percentage. This simple method has been used in climate reconstructions for many of the ice core sites across the Canadian Arctic. When summer temperatures are high enough, surface melt occurs that refreezes at depths of a few tens of centimetres and is easy to recognize, because refrozen melt has few bubbles compared to ice that forms by compression of unmelted firn (Koerner, 1977; Koerner and Fisher, 1990). Using this method, Fisher et al. (2011) have shown that recent melt rates of Canadian Arctic ice caps are the highest in four millennia and resemble those of the early Holocene optimum.

\subsection{The contribution of isotopic models}

The $\delta \mathrm{D}$ and $\delta^{18} \mathrm{O}$ of snow have long been the unique tool for reconstructing past temperatures in polar regions; these parameters are still the basis for climate reconstruction from ice cores, as they provide continuous, and potentially high resolution, records. In turn, the ice core community has a long tradition in the modelling of these isotopes, which have been incorporated into a hierarchy of models. While the dynamically simple Rayleigh model applied by Dansgaard (1964) has been extended to account for kinetic fractionation processes taking place from the oceanic surface to polar regions (Merlivat and Jouzel, 1979; Jouzel and Merlivat, 1984; Ciais and Jouzel, 1994), water isotopes have been implemented in atmospheric general circulation models (IGCMs), which allow one to account for the dynamical complexity of the Earth atmosphere.
After the pioneering work of Joussaume et al. (1984) using the LMD GCM, $\delta \mathrm{D}$ and $\delta^{18} \mathrm{O}$ were implemented in the GISS (Jouzel et al., 1987a) and ECHAM (Hoffmann and Heimann, 1993) models. Since these early IGCMs there has been an increasing interest in this approach, with currently a dozen modelling groups involved (Jouzel, 2013). Their increased spatial resolution clearly improves the data-model intercomparison on a regional scale (Fig. 8). Such models allow a direct comparison between spatial and temporal slopes by simulating different climatic periods. Using the ECHAM model, Werner et al. (2000) convincingly explained the observed discrepancy between borehole and isotope temperatures in Greenland. Instead, this same model (Hoffmann et al., 1998; Jouzel et al., 2007b) indicates that in central Antarctica the temporal slope is close to its modern spatial analogue (Fig. 8), justifying the use of presentday observations to interpret paleodata. As fully discussed in Jouzel (2013), more recent simulations (Lee et al., 2008; Sime et al., 2008, 2009; Risi et al., 2010) do not fully support this conclusion. In particular, Sime et al. $(2008,2009)$ have pointed out that using present-day observations underestimates (again with a factor of up to $\sim 2$ ) temperature changes for warmer than present-day climates in Antarctica, while Sime et al. (2013) have shown the influence of sea-ice limits on isotopic changes in Greenland.

\subsection{Combining information from $\delta \mathrm{D}, \delta^{18} \mathrm{O}$ and $\delta^{17} \mathrm{O}$}

On a global scale, precipitation $\delta \mathrm{D}$ and $\delta^{18} \mathrm{O}$ are linearly related to each other throughout the world, with a slope of about 8 (Craig, 1961) and a deuterium excess, hereafter the $d$ excess, defined as $d=\delta \mathrm{D}-8 \cdot \delta^{18} \mathrm{O}$, of about $10 \%$ (Dansgaard, 1964). Early ice core isotopic studies were based on the analysis of either $\delta^{18} \mathrm{O}$ (Dansgaard et al., 1969, 1982; Epstein et al., 1970; Johnsen et al., 1972) or $\delta \mathrm{D}$ (Lorius et al., 1979), which independently provide access to past 
temperature changes. Due to their close linear relationship, it was thought that measuring both isotopes would not bring additional climatic information, until the work of Merlivat and Jouzel (1979) showed that the $d$ excess of a precipitation is influenced by the conditions prevailing in the oceanic moisture source region (temperature, relative humidity and, to a lesser degree, wind speed). This link has further been confirmed for polar snow (Johnsen et al., 1989; Petit et al., 1991; Ciais and Jouzel, 1994); its use for extracting information about moisture sources was developed in the eighties (Jouzel et al., 1982; White et al., 1988; Dansgaard et al., 1989; Johnsen et al., 1989). Since then, $\delta \mathrm{D}$ and $\delta^{18} \mathrm{O}$ are quite systematically measured in order to provide such additional information from ice cores drilled in both Antarctica (Jouzel et al., 1982; Vimeux et al., 1999, 2002; Cuffey and Vimeux, 2001; Stenni et al., 2001, 2003, 2010; Uemura et al., 2004, 2012) and Greenland (Masson-Delmotte et al., 2005; Jouzel et al., 2007b), where deuterium excess is also used as a marker of rapid climatic changes (Steffensen et al., 2008).

In contrast, it is only recently that measurements of the triple isotopic composition of water has found applications in paleoclimatology (Landais et al., 2008; Winkler et al., 2012). Combining deuterium, oxygen 18 and oxygen 17 measurements in ice cores is promising for getting access to variations in both average temperature and relative humidity in the oceanic source region, which is not possible from $d$ excess alone. However, this approach appears more reliable for relatively coastal than for inland sites (Winkler et al., 2012).

\section{Greenhouse gases and other properties recorded in the entrapped air}

There was already an interest in entrapped air bubbles in ice cores in the sixties (Langway, 2008). Measuring their chemical composition and applying ${ }^{14} \mathrm{C}$ dating to its $\mathrm{CO}_{2}$ component - which appeared less promising than initially thought - were the main motivations of Hans Oeschger and his team for studying ice cores. In France, Dominique Raynaud developed the measurement of the total gas content, a parameter interpreted as an indicator of the change in the altitude of the ice sheet (Lorius et al., 1968; Raynaud and Lorius, 1973). However, due to the lack of a proper extraction method, it then took $10 \mathrm{yr}$ or so to reliably measure the $\mathrm{CO}_{2}$ concentration of ancient air, one common goal of the Swiss and French teams. This difficulty was overcome by Robert Delmas, Dominique Raynaud and colleagues in Grenoble, and Bernhard Stauffer and his team in Bern. The Swiss team at Byrd and the French team at Dome $\mathrm{C}$ then contributed to a major discovery and confirmed the prediction of S. Arrhenius at the end of the 19th century: at the LGM, $\mathrm{CO}_{2}$ concentration was indeed $30 \%$ less than that of the preindustrial period before human activity began to change it.

Thanks to the Vostok ice core, French researchers had access a few years later to ice covering a full glacial-interglacial cycle: throughout the last $150000 \mathrm{yr}$, $\mathrm{CO}_{2}$ concentration in entrapped air appears closely correlated with the temperature derived from the isotopic composition of the ice (Barnola et al., 1987; Jouzel et al., 1987b; Genthon et al., 1987; Raynaud et al., 1993). Colder periods are associated with lower $\mathrm{CO}_{2}$ and vice-versa, a property which holds true all along the 4 climatic cycles covered by the Vostok ice core (Petit et al., 1999). High-resolution measurements have also shown that $\mathrm{CO}_{2}$ changes are associated with millennial scale climate variations (Stauffer et al., 1998; Ahn and Brook, 2008). The Swiss and French teams have both contributed to the extension of the $\mathrm{CO}_{2}$ record over the last $800000 \mathrm{yr}$ (Siegenthaler et al., 2005; Lüthi et al., 2008). The change in pacing characterized by less warm interglacials for the earlier period (Jouzel et al., 2007a) is accompanied by a parallel change in $\mathrm{CO}_{2}$ which makes the relationship between this greenhouse and climate truly impressive (Fig. 9).

The same type of correlation - lower concentration during glacial periods than during interglacials - is observed for $\mathrm{CH}_{4}$ and $\mathrm{N}_{2} \mathrm{O}$ (Fig. 9), two greenhouse gases which also show significant increases due to human activity. Analysis of $\mathrm{CH}_{4}$ has been developed by the Bern team (Stauffer et al., 1985) and by the Grenoble team (Raynaud et al., 1988). Between the LGM and the preindustrial period, a doubling or so of $\mathrm{CH}_{4}$ has been documented (Stauffer et al., 1988). $\mathrm{N}_{2} \mathrm{O}$ also increases between these two periods (Zardini et al., 1989; Leuenberger and Siegenthaler, 1992; Sowers, 2001) and shows variations during abrupt climate changes (Flückiger et al., 1999). Obtained by Chappellaz et al. (1990), the $\mathrm{CH}_{4}$ record covering the last glacialinterglacial cycle reveals a close correlation with temperature changes and also appears influenced by monsoonal activity. It has been extended to the entire Vostok core (Petit et al., 1999) and more recently to the last $800000 \mathrm{yr}$, showing, as for $\mathrm{CO}_{2}$, lower interglacial values for the earlier period (Delmotte et al., 2004; Spahni et al., 2005; Loulergue et al., 2008). Greenland ice cores revealed another very interesting feature of the $\mathrm{CH}_{4}$ record, namely its close link with the rapid temperature warming associated with DO events (Chappellaz et al., 1993; Brook et al., 1996) and with rapid changes occuring during the last deglaciation (Severinghaus and Brook, 1999); we note here that reliable $\mathrm{CO}_{2}$ measurements are not accessible on Greenland ice due to their high level of impurities. The $\mathrm{N}_{2} \mathrm{O}$ Antarctic record shows also glacialinterglacial changes, but is disturbed by artefacts linked with elevated dust concentration (Sowers et al., 2003; Spahni et al., 2005; Schilt et al., 2009). Ice core data on more recent periods prove extremely useful to document the increases in $\mathrm{CO}_{2}, \mathrm{CH}_{4}$ and $\mathrm{N}_{2} \mathrm{O}$ over the last two centuries (MacFarling Meure et al., 2006).

For $\mathrm{CO}_{2}$, natural variations imply the circulation of the oceans and their productivity and, to a certain degree, interactions with the continental biosphere. On the contrary, variations in $\mathrm{CH}_{4}$ essentially come from the impact of the 


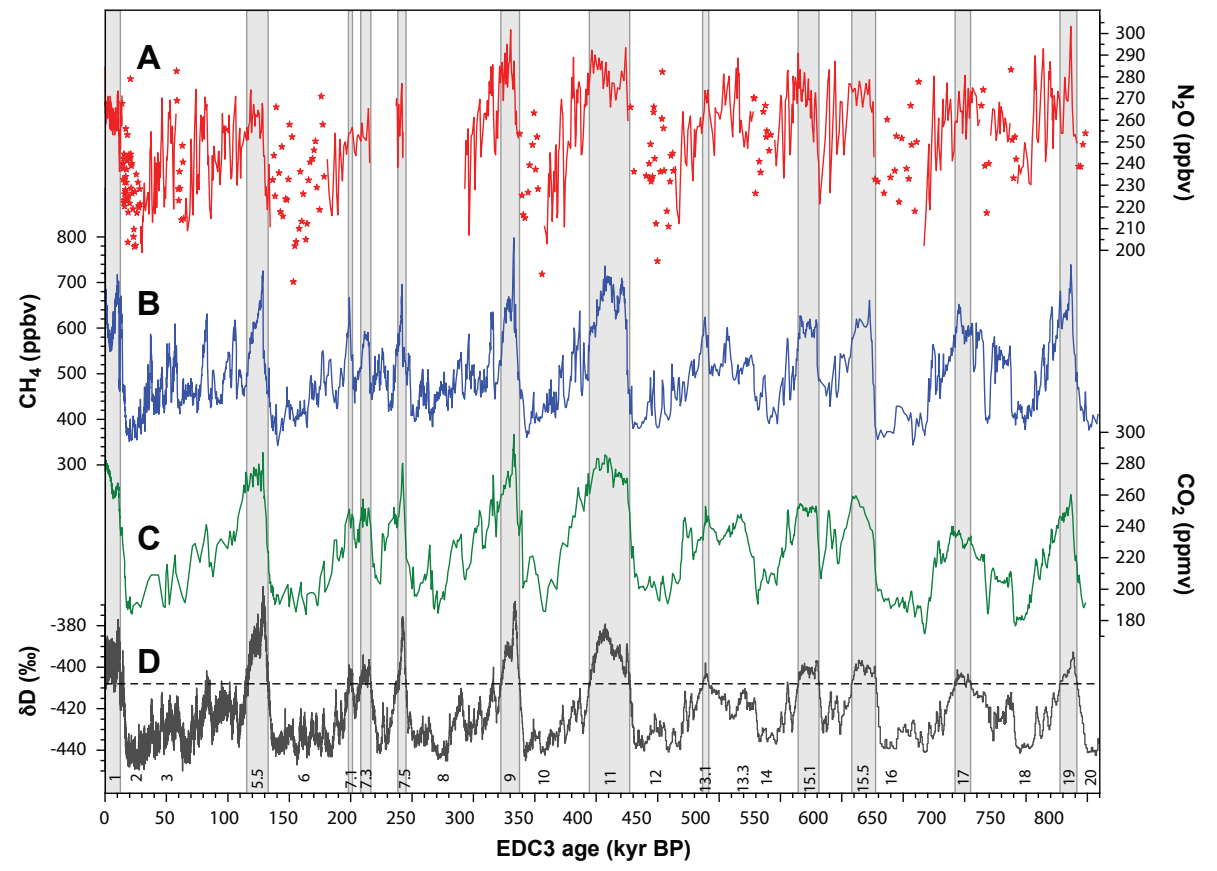

Fig. 9. Variations, over the last $800000 \mathrm{yr}$, of deuterium ( $\delta \mathrm{D}$; black), a proxy for local temperature, and the atmospheric concentrations of the greenhouse gases $\mathrm{CO}_{2}$ (green), $\mathrm{CH}_{4}$ (blue), and nitrous oxide $\left(\mathrm{N}_{2} \mathrm{O}\right.$; red) derived from air trapped within ice cores from Antarctica (Schilt et al., 2009).

climate on its earthly sources, including swamp zones and perhaps the frozen ground of high northern latitudes. Isotopic measurements, which need to be extremely precise, have allowed us to shed light on the mechanisms involved. This includes ${ }^{13} \mathrm{C}$ in $\mathrm{CO}_{2}$ (Leuenberger et al., 1992; Indermühle et al., 1999; Elsig et al., 2009; Lourantou et al., 2010; Schmitt et al., 2012), and ${ }^{13} \mathrm{C}$ (Ferretti et al., 2005; Schaefer et al., 2006; Fischer et al., 2008) and $\delta$ D (Bock et al., 2010) in methane. These results have been completed by biogeochemical modelling aiming to account for both the changes in concentrations and isotopic composition (Köhler et al., 2010; Bouttes et al., 2011). In relation with the $\mathrm{CO}_{2}$ cycle, the oxygen 17 composition of entrapped air bubbles has been measured over the last $60000 \mathrm{yr}$, allowing us to estimate the biologic oxygen productivity (Blunier et al., 2002). The isotopic composition of $\mathrm{N}_{2} \mathrm{O}\left({ }^{15} \mathrm{~N}\right.$ and $\left.{ }^{18} \mathrm{O}\right)$ also proves interesting for a better understanding of processes at the origin of atmospheric variations and of the artifacts recorded in ice cores (Sowers, 2001). Many other gaseous species such as CO (Haan et al., 1996; Haan and Raynaud, 1998; Haan et al., 1996; Haan and Raynaud, 1998), COS (Sturges et al., 2001a), various chlorine, bromine and iodide, and other species of interest for atmospheric chemistry (Sturges et al., 2001b; Reeves et al., 2005) have also been measured in firn and ice.

The Vostok data published in the eighties and nineties led to the idea that the variations in greenhouse gases have played an important climatic role in the past as amplifiers vis-à-vis changes in insolation (Genthon et al., 1987; Lorius et al., 1990; Jouzel et al., 1993; Petit et al., 1999). Further confirmed by the extension of the $\mathrm{CO}_{2}$ and $\mathrm{CH}_{4}$ records to the last $800000 \mathrm{yr}$, this interpretation - which was already taken as a clear illustration of the climatic role of $\mathrm{CO}_{2}$ at the time of the launching of the Intergovernmental Panel on Climate Change (1988) - is fully supported by climate models. At the glacial-interglacial timescale, the natural variations in concentrations of $\mathrm{CO}_{2}$ and $\mathrm{CH}_{4}$ are equivalent to those linked to human activity during the last two hundred years. The correlation between the greenhouse effect associated with these two gases led Lorius et al. (1990) to propose an estimate of the climate sensitivity (e.g. for $\mathrm{CO}_{2}$ doubling) based on paleodata. They inferred a range of $\sim 3$ to $4^{\circ} \mathrm{C}$, in broad agreement with currently cited values $\left(2\right.$ to $4.5^{\circ} \mathrm{C}$ as in IPCC, 2007).

The approach followed by Lorius et al. (1990) did not require that the complexity of the mechanisms of glacialinterglacial climatic changes be completely deciphered or that a definitive response to the "chicken or egg" question be given: which is the cause, which is the effect? Indeed, there is a difficulty in determining precisely the timing between greenhouse and climate changes because of the uncertainty associated with the difference between the age of the gas, estimated from a firnification model (Barnola et al., 1991), and the age of the ice; at low accumulation sites such as Vostok, this uncertainty can be higher than $1000 \mathrm{yr}$ (Petit et al., 1999). Based on this approach, two studies pointed to a lead of Antarctic warming with respect to the $\mathrm{CO}_{2}$ increase 
during the last 3 terminations (Fischer et al., 1999; Monnin et al., 2001). Caillon et al. (2003) confirmed this result for termination III from a completely different method based on the surprising similarity between the $\delta \mathrm{D}\left(\right.$ or $\left.\delta^{18} \mathrm{O}\right)$ of ice and the isotopic composition of argon - then taken as a proxy of climate change in the gas phase. However, the existence of such a lead is now challenged by a third method: using the air $\delta^{15} \mathrm{~N}$ to determine the depth at which air in the ice is permanently trapped, Parrenin et al. (2013) concluded that Antarctic temperature did not began to rise before $\mathrm{CO}_{2}$ during termination I.

Other properties are recorded in the entrapped air bubbles. In collaboration with French colleagues, Michael Bender pioneered the measurement oxygen 18 of $\mathrm{O}_{2}$, focusing on the last deglaciation (Bender et al., 1985). This parameter is influenced by the productivity of the continental and oceanic biosphere and by the $\delta^{18} \mathrm{O}$ of continental and oceanic waters, and thus sea-level change (Bender et al., 1994a; Sowers et al., 1991; Malaizé et al., 1999; Jouzel et al., 1996; Severinghaus et al., 2009; Landais et al., 2010). The extension of this record (Jouzel et al., 1996; Petit et al., 1999; Kawamura et al., 2007; Dreyfus et al., 2007; Landais et al., 2010) pointed to the influence of insolation changes with the presence of a strong precessional cycle which has been used to place chronological constraints on the chronologies of the Vostok, Dome F and EPICA Dome C cores. Bender was also at the origin of the discovery of a link between small measured variations of the $\mathrm{N}_{2} / \mathrm{O}_{2}$ ratio and insolation changes (Bender, 2002). Although not fully understood, these variations which are linked to the firnification process are now extensively used for dating purposes (Kawamura et al., 2007, 2012; Suwa and Bender, 2008; Landais et al., 2012). The same applies for the record of total gas content; beyond being influenced by the air pressure and thus the altitude of the ice sheet (Raynaud and Lorius, 1973), the obliquity cycle is clearly imprinted in the glacial-interglacial record (Raynaud et al., 2007; Lipenkov et al., 2011). Vinther et al. (2009) pointed out that this gas content information confirms the Holocene thinning of the Greenland ice sheet derived by combining isotopic data from deep ice cores (Camp Century, Dye 3, GRIP and North GRIP) and from ice cores from small marginal ice caps (Renland and Agassiz); this approach gives a convincing example of how one can separate the Greenland temperature and surface elevation histories.

Understanding the link between isotopic records from both polar regions became a topic of interest in the nineties (Jouzel et al., 1994; Bender et al., 1994b). Establishing this link has considerably benefitted from measurements of properties such as $\delta^{18} \mathrm{O}$ of $\mathrm{O}_{2}$ and methane concentration, which should show similar variations in air entrapped either in Greenland or in Antarctic ice, except for the existence of a small interpolar $\mathrm{CH}_{4}$ gradient (Dällenbach et al., 2000). This approach was first applied using slow changes of $\delta^{18} \mathrm{O}$ of $\mathrm{O}_{2}$ (Bender et al., 1994b, 1999) and then developed using well-defined methane variations (Blunier et al., 1998;
Blunier and Brook, 2001; Morgan et al., 2002). This allowed one to correlate Greenland and Antarctic records, showing that abrupt Greenland events have smooth counterparts in Antarctica with, in general, the onset of isotopic changes preceding the onset in Greenland by 1500 to $3000 \mathrm{yr}$, whereas their maxima are apparently coincident. This one-to-one coupling (EPICA Community Members, 2006), which supports the bipolar seesaw hypothesis (Broecker, 1998; Stocker and Johnsen, 2003), has been fully confirmed from the comparison of the $\delta^{18} \mathrm{O}$ records obtained along the North GRIP and EDML cores (Fig. 10). Note that recent studies have also demonstrated the possibility of directly and closely correlating ice records from Greenland and Antarctica, at least for some specific time periods. This is done using either the welldefined beryllium 10 peak around $41000 \mathrm{yr}$ ago (Raisbeck et al., 2007) or easily identifiable volcanic events (Svensson et al., 2013), and allows one to test the reliability of gas age-ice age estimates.

Beyond their use for correlating Greenland and Antarctic ice cores, measurements of $\delta^{18} \mathrm{O}$ of $\mathrm{O}_{2}$ and of $\mathrm{CH}_{4}$ have been applied to identify stratigraphic disturbances in the deepest parts of Greenland ice cores. Due to the proximity of the bedrock, such disturbances can be identified by a mismatch between the gas records derived for a given period from this Greenland ice and from the Antarctic undisturbed record (Bender et al., 1994b; Fuchs and Leuenberger, 1996; Chappellaz et al., 1997), and/or by the lack of a depth difference between a climatic event, such as a rapid change, recorded both in the ice and in the entrapped air (Landais et al., 2004c). Combined with isotopic measurements in ice, these gas data can also be used to recontruct, at least partly, the correct ice sequence (Landais et al., 2003; Suwa et al., 2006). The same strategy has been used to extend the Greenland Eemian sequence from the NEEM folded ice core, partly covered in the North GRIP core (North GRIP community, 2004), back to $128.5 \mathrm{kyr}$ BP (NEEM community).

\section{Future challenges}

Thanks to pioneers who initiated ice core drilling in Greenland, Antarctica and in non-polar glaciers, to their scientific and technical teams, to the continuous development of drills and to their successful deployment, to the logistical and financial support of numerous organisations, to international collaborations and to their capacity to continuously attract young scientists, the ice core community can be proud of what has been achieved and produced since the first deep drilling which allowed it to recover ice from the last glacial period (1966 at Camp Century). This applies to the topics on which I have focused (mainly climate and atmospheric composition) and holds equally true for the aspects I have not covered (atmospheric chemistry, biogeochemical cycles, cosmogenic isotopes, physics of ice, modelling of ice sheets). Beyond shedding light on past changes, ice cores provide 


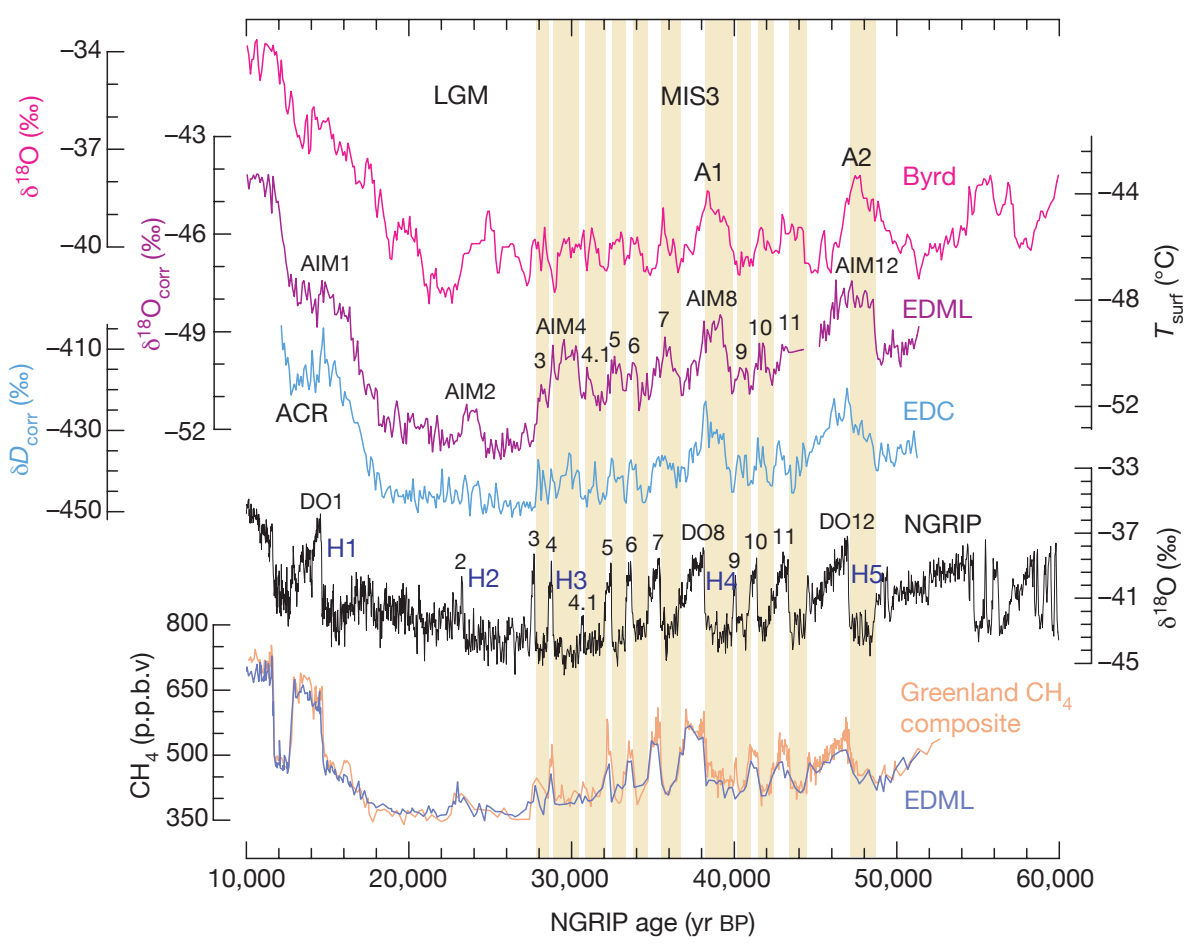

Fig. 10. Methane synchronization of the EDML and the NGRIP records reveals a one-to-one assignment of each Antarctic warming with a corresponding stadial in Greenland (adapted from EPICA Community Members, 2006)

a lot of information relevant to future climate change, with the discovery, in Antarctica, of a strong link between greenhouse gases and climate over the last $800000 \mathrm{yr}$ and of rapid and abrupt climate changes in Greenland. They allow us to document past climate variability at various time scales, contribute to establishing the links between climate changes in the Northern and Southern hemispheres. They are unique in that they provide access to past climate forcings. This includes greenhouse gases but also solar (from cosmegenic isotopes), volcanic and other aerosols forcings (from the chemical composition of the ice) allowing them to test the sensitivity of climate models and their ability to identify the contribution of human activities to recent climate change.

Future challenges in ice core research are well taken into account by the four projects defined by IPICS (Brook et al., 2006): (1) to get a 1.5 million year record of climate and greenhouse gases from Antarctica, (2) to cover the Last Interglacial and beyond in Greenland, (3) to build a network of bipolar ice core records spanning the past $40000 \mathrm{yr}$ and (4) to get ultra-high-resolution records of climate variability and climate forcings spanning the past $2000 \mathrm{yr}$. Projects dealing with the latter objectives (2000 and $40000 \mathrm{yr}$ ) have developed since the launching of the IPICS initiative, but after the drilling of NEEM, it appears more challenging than initially thought to get an undisturbed ice core reaching back the previous glacial period in Greenland.

The case for extending the ice core record to $1.5 \mathrm{Ma}$, very well established by the IPICS initiative (IPICS, 2008), is indeed reinforced by results recently published by the deepsea core community. For the oldest half of this period, we are mainly reliant on marine sediment records which allow us to depict the transition from a $40 \mathrm{ka}$ world to a world dominated by a 100 ka cyclicity, and point to a shift corresponding to the start of the Mid-Pleistocene Transition (MPT) 1.25 Ma ago. Despite rapid progresses in the reconstruction of past atmospheric $\mathrm{CO}_{2}$ concentration from various proxies in terrestrial and marine archives, there is still a need for a direct and detailed determination from air bubbles trapped in ice cores (Jouzel and Masson-Delmotte, 2010b). In this scientifically very exciting context, the major challenge of the ice core community concerns the selection of the best possible drilling site to obtain undisturbed records covering the last 1.5 Ma in Antarctica and the last $150 \mathrm{ka}$ in Greenland. Highresolution cartographies, radar mapping as well as high resolution modelling will be needed. In a recent article, Fischer et al. (2013) strongly argue for significantly reduced ice thickness (maximum of $\sim 2500 \mathrm{~m}$ ) to avoid basal melting which leads to loss of ice and diminishes the age of the ice at the bottom. Because of the huge logistical costs to set up a new base in remote places in central Antarctica, new rapid reconnaissance technologies can be envisaged to qualify the chosen drilling site at low cost (Severinghaus et al., 2010). For example, an innovative instrument combining a drill and a probe is currently being developed (Chappellaz et al., 2012); it would allow one, within one field season, to drill down through $3 \mathrm{~km}$ of ice and at the same time to measure key 
parameters such as water isotopic composition and greenhouse gas composition. Similar projects which were developed and tested (unfortunately without success) in the seventies and eighties both in Greenland and Antarctica, are being or have been explored by other groups in Switzerland and in the USA. Such technology would also provide preliminary climate information prior to the heavy deep drilling operations. Given its high expected outcome, the opportunity for new technological breakthroughs and the ongoing international collaborative effort of the ice core community under IPICS, one should be optimistic about the recovery in the coming years of one, or better several, very old Antarctic ice cores spanning the MPT transition.

Acknowledgements. I would like to thank the ice core community as a whole - drillers, logisticians, scientists and technicians and others - and all the organisations which have supported ice core research, for their invaluable contribution to our knowledge and understanding of climate and environmental changes. It is an honour, and a great pleasure, to be part of this community. I would like also to acknowledge J. P. Steffensen and an anonymous reviewer for their very thorough reviews, and David Fisher for his comments.

Edited by: E. Wolff

\section{References}

Ahn, J. and Brook, E. J.: Atmospheric $\mathrm{CO}_{2}$ and climate on millennial time scales during the last glacial period, Science, 322, 83-85, doi:10.1126/science.1160832, 2008.

Alley, R. B.: The Two-Mile Time Machine: Ice Core, Abrupt Climate Change and Our Future, Princeton University Press, Princeton, 2000.

Alley, R. B., Meese, D. A., Shuman, C. A., Gow, A. J., Taylor, K. C., Grootes, P. M., White, J. W. C., Ram, M., Waddington, E. D., Mayewski, P. A., and Zielinski, G. A.: Abrupt increase in Greenland snow accumulation at the end of the Younger Dryas event, Nature, 362, 527-529, 1993.

Alley, R. B., Shuman, C. A., Meese, D. A., Gow, A. J., Taylor, K. C., Cuffey, K. M., Fitzpatrick, J. J., Grootes, P. M., Zielinski, G. A., Ram, M., Spinelli, G., and Elder, B.: Visualstratigraphic dating of the GISP2 ice core: basic, reproducibility, and application, J. Geophys. Res., 102, 26367-26381, 1997.

Aristarain, A., Jouzel, J., and Pourchet, M.: Past Antarctic Peninsula Climate (1850-1980) deduced from an ice core isotope record, Climatic Change, 8, 69-90, 1986.

Aristarain, A., Jouzel, J., and Lorius, C.: A 400 years isotope record of the Antarctic Peninsula climate, Geophys. Res. Lett., 17, 2369-2372, 1990.

Arnaud, L., Barnola, J.-M., and Duval, P.: Physical modeling of the densification of snow/firn and ice in the upper part of polar ice sheets, in: Physics of Ice Core Records, edited by: Hondoh, T., Hokkaido University Press, Sapporo, 285-305, 2000.

Barnola, J.-M., Raynaud, D., Korotkevich, Y. N., and Lorius, C.: Vostok ice-core provides $160,000 \mathrm{yr}$ record of atmospheric $\mathrm{CO}_{2}$, Nature, 329, 408-414, 1987.
Barnola, J. M., Pimienta, P., Raynaud, D., and Korotkevich, Y. S.: $\mathrm{CO}_{2}$ climate relationship as deduced from the Vostok ice core: a re-examination based on new measurements and on a reevaluation of the air dating, Tellus B, 43, 83-91, 1991.

Bazin, L., Landais, A., Lemieux-Dudon, B., Toyé Mahamadou Kele, H., Veres, D., Parrenin, F., Martinerie, P., Ritz, C., Capron, E., Lipenkov, V., Loutre, M.-F., Raynaud, D., Vinther, B., Svensson, A., Rasmussen, S. O., Severi, M., Blunier, T., Leuenberger, M., Fischer, H., Masson-Delmotte, V., Chappellaz, J., and Wolff, E.: An optimized multi-proxy, multi-site Antarctic ice and gas orbital chronology (AICC2012): 120-800 ka, Clim. Past, 9, 17151731, doi:10.5194/cp-9-1715-2013, 2013.

Bender, M. L.: Orbital tuning chronology for the Vostok climate record supported by trapped gas composition, Earth Planet. Sc. Lett., 204, 275-289, 2002.

Bender, M. L., Labeyrie, L., Raynaud, D., and Lorius, C.: Isotopic composition of atmospheric $\mathrm{O}_{2}$ in ice linked with deglaciation and global primary productivity, Nature, 318, 349-352, 1985.

Bender, M. L., Sowers, T., and Labeyrie, L.: The Dole effect and its variations during the last 130000 years as measured in the Vostok ice core, Global Biogeochem. Cy., 8, 363-376, 1994a.

Bender, M. L., Sowers, T., Dickson, M. L., Orchado, J., Grootes, P., Mayewski, P. A., and Meese, D. A.: Climate connection between Greenland and Antarctica during the last 100000 years, Nature, 372, 663-666, 1994b.

Bender, M. L., Malaizé, B., Orchado, J., Sowers, T., and Jouzel, J.: High precision correlations of Greenland and Antarctic ice core records over the last $100 \mathrm{kyr}$, in: Mechanisms of Global Climate Change at Millenial Timescales, Geophysical Monograph, 112, edited by: Clark, P. U., Webb, R. S., and Keigwin, L. D., AGU, Washington, D.C., 149-164, doi:10.1029/GM112p0149, 1999.

Blunier, T. and Brook, E. J.: Timing of millenial-scale climate change in Antarctica and Greenland during the Last Glacial Period, Science, 291, 109-112, 2001.

Blunier, T., Chappellaz, J., Schwander, J., Dällenbach, A., Stauffer, B., Stocker, T., Raynaud, D., Jouzel, J., Clausen, H. B., Hammer, C. U., and Johnsen, S. J.: Asynchrony of Antarctic andGreenland climate change during the last glacial period, Nature, 394, 739743, 1998.

Blunier, T., Barnett, B., Bender, M. L., and Hendricks, M. B.: Biological oxygen productivity during the last 60000 years from triple oxygen isotope measurements, Global Biogeochem. Сy., 16, 1029, doi:10.1029/2001GB001460, 2002.

Blunier, T., Schwander, J., Chappellaz, J., and Parrenin, F.: What was the surface temperature in central Antarctica during the last glacial maximum ?, Earth Planet. Sc. Lett., 218, 379-388, 2004.

Bock, M., Schmitt, J., Moeller, L., Spahni, R., Blunier, T., and Fischer, $\mathrm{H}$.: Hydrogen isotopes preclude marine hydrate $\mathrm{CH}_{4}$ emissions at the onset of Dansgaard-Oeschger events, Science, 328, 1686-1689, doi:10.1126/science.1187651, 2010.

Bouttes, N., Paillard, D., Roche, D. M., Brovkin, D. M., and Bopp, L.: Last Glacial Maximum $\mathrm{CO}_{2}$ and $\delta^{13} \mathrm{C}$ successfully reconciled, Geophys. Res. Lett., 38, L02705, doi:10.1029/2010GL044499, 2011.

Broecker, W. S.: Paleocean circulation during the last deglaciation: a bipolar seesaw?, Paleoceanography, 13, 119-121, 1998.

Broecker, W. S., Peteet, D. M., and Rind, D.: Does the oceanatmosphere system have more than one stable mode of operation?, Nature, 315, 21-26, doi:10.1038/315021a0, 1985. 
Brook, E. J., Sowers, T., and Orchardo, J.: Rapid variations in atmospheric methane concentration during the past 110000 years, Science, 273, 1087-1091, 1996.

Brook, E. J., Wolff, E., Dahl-Jensen, D., Fischer, H., and Steig, E.: The future of ice coring, International Partnership in Ice Core Sciences (IPICS), PAGES News, 14, 6-10, 2006.

Caillon, N., Severinghaus, J. P., Barnola, J. M., Chappellaz, J. C., Jouzel, J., and Parrenin, F.: Estimation of temperature change and of gas age-ice age difference, $108 \mathrm{kyr}$ BP, at Vostok, Antarctica, J. Geophys. Res., 106, 31893-31901, 2001.

Caillon, N., Severinghaus, J. P., Jouzel, J. P., Barnola, J. M., Kang, J., and Lipenkov, V. Y.: Timing of atmospheric $\mathrm{CO}_{2}$ and Antarctic temperature changes across termination III, Science, 299, 1728-1731, 2003.

Capron, E., Landais, A., Chappellaz, J., Schilt, A., Buiron, D., Dahl-Jensen, D., Johnsen, S. J., Jouzel, J., Lemieux-Dudon, B., Loulergue, L., Leuenberger, M., Masson-Delmotte, V., Meyer, H., Oerter, H., and Stenni, B.: Millennial and sub-millennial scale climatic variations recorded in polar ice cores over the last glacial period, Clim. Past, 6, 345-365, doi:10.5194/cp-6-3452010, 2010.

Chappellaz, J., Barnola, J. M., Raynaud, D., Korotkevich, Y. S., and Lorius, C.: Ice-core record of atmospheric methane over the past 160000 years, Nature, 345, 127-131, 1990.

Chappellaz, J., Blunier, T., Barnola, J. M., Raynaud, D., Schwander, J., and Stauffer, B.: Synchronous changes in atmospheric $\mathrm{CH}_{4}$ and Greenland climate between 40 and 8 kyr BP, Nature, 366, 443-445, 1993.

Chappellaz, J., Brook, E., Blunier, T. and Malaizé B.: $\mathrm{CH}_{4}$ and $\delta^{18} \mathrm{O}$ of $\mathrm{O}_{2}$ records from Antarctic and Greenland ice: A clue for stratigraphic disturbance in the bottom part of the Greenland Ice Core Project and the Greenland Ice Sheet Project 2 ice cores, J. Geophys. Res., 102, 26547-26557, 1997.

Chappellaz, J., Alemany, O., Romanini, D., and Kerstel, E.: The IPICS "oldest ice" challenge: a new technology to qualify potential sites, Ice Snow, 4, 57-64, 2012.

Ciais, P. and Jouzel, J.: Deuterium and oxygen 18 in precipitation: an isotopic model including mixed cloud processes, J. Geophys. Res., 99, 16793-16803, 1994.

Ciais, P., Petit, J. R., Jouzel, J., Lorius, C., Barkov, N. I., Lipenkov, V., and Nicolaïev, V.: Evidence for an early Holocene climatic optimum in the Antarctic deep ice core record, Clim. Dynam., 6, 169-177, 1992.

Craig, H.: Isotopic variations in meteoric waters, Science, 133, 1702-1703, 1961.

Cuffey, K. M. and Vimeux, F.: Covariation of carbon dioxyde and temperature from the Vostok ice core after deuterium-excess correction, Nature, 421, 523-527, 2001.

Cuffey, K. M., Clow, G. D., Alley, R. B., Stuiver, M., Waddington, E. D., and Saltus, R. W.: Large Arctic temperature change at the Winconsin-Holocene glacial transition, Science, 270, 455-458, 1995.

Dahl-Jensen, D., Mosegaard, K., Gundestrup, N., Clow, G. D., Johnsen, S. J., Hansen, A. W., and Balling, N.: Past temperatures directly from the Greenland ice sheet, Science, 282, 268-271, 1998.
Dällenbach, A., Blunier, T., Flückiger, J., Stauffer, B., Chappellaz, J., and Raynaud, D.: Changes in the atmospheric $\mathrm{CH}_{4}$ gradient between Greenland and Antarctica during the Last Glacial and the transition to the Holocene, Geophys. Res. Lett., 27, 10051008, 2000.

Dansgaard, W.: The abundance of ${ }^{18} \mathrm{O}$ in atmospheric water and water vapour, Tellus, 5, 461-469, 1953.

Dansgaard, W.: Stable isotopes in precipitation, Tellus, 16, 436468, 1964.

Dansgaard, W.: Frozen Annals, Niels Bohr Institute, Copenhagen, Denmark, 2004.

Dansgaard, W., Johnsen, S. J., Moller, J., and Langway, C. C. J.: One thousand centuries of climatic record from Camp Century on the Greenland ice sheet, Science, 166, 377-381, 1969.

Dansgaard, W., Clausen, H. B., Gundestrup, N., Hammer, C. U., Johnsen, S. J., Krinstindottir, P., and Reeh, N.: A new Greenland deep ice core, Science, 218, 1273-1277, 1982.

Dansgaard, W., Johnsen, S., Clausen, H. B., Dahl-Jensen, D., Gundestrup, N., Hammer, C. U., and Oeschger, H.: North Atlantic climatic oscillations revealed by deep Greenland ice cores, in: Climate Processes and Climate Sensitivity, edited by: Hansen, J. E. and Takahashi, T., Am. Geophys. Union, Washington, D.C., 288-298, doi:10.1029/GM029p0288, 1984.

Dansgaard, W., White, J. W. C., and Johnsen, S. J.: The abrupt termination of the Younger Dryas, Nature, 339, 532-534, 1989.

Dansgaard, W., Johnsen, S. J., Clausen, H. B., Dahl-Jensen, D., Gunderstrup, N. S., Hammer, C. U., Steffensen, J. P., Sveinbjörnsdottir, A., Jouzel, J., and Bond, G.: Evidence for general instability of past climate from a 250-kyr ice-core record, Nature, 364, 218-220, 1993.

Delmas, R. J., Ascensio, J. M., and Legrand, M.: Polar ice evidence that atmospheric $\mathrm{CO}_{2} 20000 \mathrm{yr}$ BP was $50 \%$ of present, Nature, 284, 155-157, 1980.

Delmotte, M., Chappellaz, J., Brook, E., Yiou, P., Barnola, J. M., Goujon, C., Raynaud, D., and Lipenkov, V. I.: Atmospheric methane during the last four glacial-interglacial cycles: rapid changes and their link with Antarctic temperature, J. Geophys. Res., 109, D12104, doi:10.1029/2003JD004417, 2004.

Dreyfus, G. B., Parrenin, F., Lemieux-Dudon, B., Durand, G., Masson-Delmotte, V., Jouzel, J., Barnola, J.-M., Panno, L., Spahni, R., Tisserand, A., Siegenthaler, U., and Leuenberger, M.: Anomalous flow below $2700 \mathrm{~m}$ in the EPICA Dome $\mathrm{C}$ ice core detected using $\delta^{18} \mathrm{O}$ of atmospheric oxygen measurements, Clim. Past, 3, 341-353, doi:10.5194/cp-3-341-2007, 2007.

Dunbar, N. W., McIntosh, W. C., and Esser, R. P.: Physical setting and tephrochronology of the summit caldera ice record at Mount Moulton, West Antarctica, GSA Bull., 120, 796-812, 2008.

Elsig, J., Schmitt, J., Leuenberger, D., Schneider, R., Eyer, M., Leuenberger, M., Joos, F., Fischer, H., and Stocker, T. F.: Stable isotope constraints on Holocene carbon cycle changes from an Antarctic ice core, Nature, 461, 507-510, doi:10.1038/nature08393, 2009.

EPICA Community Members: Eight glacial cycles from an Antarctic ice core, Nature, 429, 623-628, 2004.

EPICA Community Members: Interhemispheric coupling of millenial scale variability during the last glacial, Nature, 444, 195198, 2006. 
Epstein, S., Sharp, R. P., and Gow, A. J.: Antarctic ice sheet: stable isotope analyses of Byrd station cores and interhemispheric climatic implications, Science, 16, 1570-1572, 1970.

Ferretti, D. F., Miller, J. B., White, J. W. C., Etheridge, D. M., Lassey, K. R., Lowe, D. C., MacFarling Meure, C. M., Dreier, M. F., Trudinger, C. M., van Ommen, T. D., and Langenfelds, R. L.: Unexpected changes to the global methane budget over the past 2000 years, Science, 309, 1714-1717, 2005.

Fischer, H., Wahlen, M., Smith, J., Mastroianni, D., and Deck, B.: Ice core records of atmospheric $\mathrm{CO}_{2}$ around the last three glacial terminations, Science, 283, 1712-1714, 1999.

Fischer, H., Behrens, M., Bock, M., Richter, U., Schmitt, J., Loulergue, L., Chappellaz, J., Spahni, R., Blunier, T., Leuenberger, M., and Stocker, T. F.: Changing boreal methane sources and constant biomass burning during the last termination, Nature, 452, 864-867, doi:10.1038/nature06825, 2008.

Fischer, H., Severinghaus, J., Brook, E., Wolff, E., Albert, M., Alemany, O., Arthern, R., Bentley, C., Blankenship, D., Chappellaz, J., Creyts, T., Dahl-Jensen, D., Dinn, M., Frezzotti, M., Fujita, S., Gallee, H., Hindmarsh, R., Hudspeth, D., Jugie, G., Kawamura, K., Lipenkov, V., Miller, H., Mulvaney, R., Pattyn, F., Ritz, C., Schwander, J., Steinhage, D., van Ommen, T., and Wilhelms, F.: Where to find 1.5 million yr old ice for the IPICS "Oldest Ice" ice core, Clim. Past Discuss., 9, 2771-2815, doi:10.5194/cpd-92771-2013, 2013.

Fisher, D. A., Koerner, R. M., Paterson, W. S. B., Dansgaard, W., Gundestrup, N., and Reeh, N.: Effect of wind scouring on climatic records from ice-core oxygen-isotope profiles, Nature, 301, 205-209, 1983.

Fisher, D. A., Koerner, R. M., Bourgeois, J. C., Zielinski, G., Wake, C., Hammer, C. U., Clausen, H. B., Gundestrup, N., Johnsen, S., Goto-Azuma, K., Hondoh, T., Blake, E., Gerasimoff, M.: Penny Ice Cap, Baffin Island, Canada and the Wisconsinan Foxe Dome connection: two states of Hudson Bay ice cover, Science, 279, 692-695, 1998.

Fisher, D., Zheng, J., Burgess, D., Zdanowicz, C., Kinnard, C., Sharp, M., and Bourgeois, J.: Recent melt rates of Canadian arctic ice caps are the highest in four millennia, Global Planet. Change, doi:10.1016/j.gloplacha.2011.06.005, in press, 2011.

Flückiger, J., Dällenbach, A., Blunier, T., Stauffer, B., Stocker, T. F., Raynaud, D., and Barnola, J. M.: Variations in atmospheric $\mathrm{N}_{2} \mathrm{O}$ concentration during abrupt climatic changes, Science, 285, 227-230, 1999.

Fuchs, A., and Leuenberger, M. C.: $\delta^{18} \mathrm{O}$ of atmospheric oxygen measured on the GRIP ice core document stratigraphic disturbances in the lowest $10 \%$ of the core, Geophys. Res. Lett., 23, 1049-1052, 1996.

Genthon, C., Barnola, J. M., Raynaud, D., Lorius, C., Jouzel, J., Barkov, N. I., Korotkevitch, Y. S., and Kotlyakov, V. M.: Vostok ice core: the climate response to and orbital forcing changes over the last climatic cycle (160000 years), Nature, 329, 414-418, 1987.

Gow, A. J. and Engelhart, H.: Preliminary analysis of ice core from Siple Dome, West Antarctica, in: Physics of Ice Core Records, edited by: Hondoh, T., Hokkaido University Press, Sapporo, 64$82,2000$.
Grootes, P. M., Stuiver, M., White, J. W. C., Johnsen, S. J., and Jouzel, J.: Comparison of the oxygen isotope records from the GISP2 and GRIP Greenland ice cores, Nature, 366, 552-554, 1993.

Grootes, P. M., Steig, E. J., Stuiver, M., Waddington, E. D., and Morse, D. L.: A new ice core record from Taylor Dome, Antarctica, EOS Transactions, 75, 225, 1994.

Haan, D. and Raynaud, D.: Ice core record of CO variations during the last two millennia: atmospheric implications and chemical interactions within the Greenland ice, Tellus B, 50, 253-262, 1998.

Haan, D., Martinerie, P., and Raynaud, D.: Ice core data of atmospheric carbon monoxide over Antarctica and Greenland during the last 200 years, Geophys. Res. Lett., 23, 2235-2238, 1996.

Hamley, T. C., Morgan, V. I., Thwaites, R. J., and Gao, X. Q.: An ice-core drilling site at Law Dome summit, Wilkes Land, Antarctica, ANARE Research Notes 37, AAS Projects 15, Information Services Section, Antarctic Division, Dept. of Science and Technology, Kingston, Tasmania, Australia, 34 pp., 1986.

Hammer, C. U., Clausen, H. B., and Tauber, H.: Ice-core dating of the Pleistocene/Holocene boundary applied to a calibration of the ${ }^{14} \mathrm{C}$ time scale, Radiocarbon, 28, 284-291, 1986.

Hansen, L. B. and Langway Jr., C. C.: Deep core drilling in ice and core analysis at Camp Century, Greenland, 1961-1966, Antarct J. US, 207-208, 1966.

Hays, J. D., Imbrie, J., and Shackleton, N. J.: Variations in the Earth's orbit: pacemaker of the ice ages, Science, 194, 11211132, 1976.

Headly, M. A. and Severinghaus, J.: A method to measure Kr/N2 ratios in air bubbles trapped in ice cores and its application in reconstructing past mean ocean temperature, J. Geophys. Res., 112, D19105, doi:10.1029/2006JD008317, 2007.

Heuberger, J. C.: Groenland, glaciology, Forages sur I'inlandis, Hermann and Cie, Paris, 1, 63-84, 1954.

Hoffmann, G. and Heimann, M.: Water tracers in the ECHAM general circulation model, in: Isotope Techniques in the Study of Past and Current Environmental Changes in the Hydrosphere and the Atmosphere, International Atomic Energy Agency, Vienna, 3-14, 1993.

Hoffmann, G., Werner, M., and Heimann, M.:Water isotope module of the ECHAM Atmospheric General Circulation Model: a study on time scales from days to several years, J. Geophys. Res., 103, 16871-16896, 1998.

Huber, C., Leuenberger, M., Spahni, R., Flückiger, J., Schwander, J., Stocker, T. F., Johnsen, S., Landais, A., and Jouzel, J.: Isotope calibrated Greenland temperature record over marine isotope stage 3 and its relation to $\mathrm{CH}_{4}$, Earth Planet. Sc. Lett., 243, 504-519, 2006.

Indermühle, A., Stocker, T. F., Joos, F., Fischer, H., Smith, H. J., Wahlen, M., Deck, B., Mastroianni, D., Tschumi, J., Blunier, T., Meyer, R., and Stauffer, B.: Holocene carbon cycle dynamics based on $\mathrm{CO}_{2}$ trapped in ice at Taylor Dome, Antarctica, Nature, 398, 121-126, doi:10.1038/18158, 1999.

IPCC: Summary for Policymakers, in: Climate Change 2007: The Physical Science Basis, Contribution of Working Group I to the Fourth Assessment Report of the Intergovernmental Panel on Climate Change, edited by: Solomon, S., Qin, D., Manning, M., Chen, Z., Marquis, M., Averyt, K. B., Tignor, M., and Miller, H. L., Cambridge University Press, Cambridge, UK and New York, NY, USA. 
IPICS white paper: The oldest ice core: A 1.5 million year record of climate and greenhouse gases from Antarctica, Science and outline implementation plan, http://www.pages-igbp.org/ipics/ (last access: November 2013), 2008.

Johnsen, S. J.: Stable isotope homogenization of polar firn and ice, Proc. Symp. on Isotopes and Impurities in Snow and Ice, I.U.G.G. XVI, General Assembly, Grenoble August September 1975, Washington, 210-219, 1977.

Johnsen, S. J., Dansgaard, W., Clausen, H. B., and Langway, C. C.: Oxygen isotope profiles through the Antarctic and Greenland ice sheets, Nature, 235, 429-434, 1972.

Johnsen, S. J., Dansgaard, W., and White, J. W. C.: The origin of Arctic precipitation under present and glacial conditions, Tellus, 41, 452-469, 1989.

Johnsen, S. J., Clausen, H. B., Dansgaard, W., Fuhrer, K., Gunderstrup, N. S., Hammer, C. U., Iverssen, P., Jouzel, J., Stauffer, B., and Steffensen, J. P.: Irregular glacial interstadials recorded in a new Greenland ice core, Nature, 359, 311-313, 1992.

Johnsen, S. J., Dahl-Jensen, D., Dansgaard, W., and Gundestrup, N.: Greenland paleotemperatures derived from GRIP bore hole temperature and ice core isotope profiles, Tellus B, 47, 624-629, 1995.

Johnsen, S. J., Clausen, H. B., Cuffey, K. M., Hoffmann, G., Schwander, J., and Creyts, T.: Diffusion of stable isotopes in polar firn and ice: the isotope effect in firn diffusion, in: Physics of Ice Core Records, 159, edited by: Hondoh, T., Hokkaido University Press, Sapporo, 121-140, 2000.

Joussaume, S., Jouzel, J., and Sadourny, R.: A general circulation model of water isotope cycles in the atmosphere, Nature, 311, 24-29, 1984.

Jouzel, J.: Water stable isotopes: atmospheric composition and applications in polar ice core studies, in: Handbook of Geochemistry, Elsevier Ltd, 2013.

Jouzel, J. and Masson-Delmotte, V.: Paleoclimates: what do we learn from ice cores?, Climatic Change, 1, 654-669, 2010a.

Jouzel, J. and Masson-Delmotte, V.: Deep ice cores: the need for going back in time, Quaternary Sci. Rev., 29, 3683-3689, 2010b.

Jouzel, J. and Merlivat, L.: Deuterium and oxygen 18 in precipitation: modeling of the isotopic effects during snow formation, J. Geophys. Res., 89, 11749-11757, 1984.

Jouzel, J. and Souchez, R. A.: Melting refreezing at the glacier and the isotopic composition of the ice, J. Glaciol., 28, 34-42, 1982.

Jouzel, J., Merlivat, L., and Lorius, C.: Deuterium excess in an East Antarctic ice core suggests higher relative humidity at the oceanic surface during the last glacial maximum, Nature, 299, 688-691, 1982.

Jouzel, J., Russell, G. L., Suozzo, R. J., Koster, R. D., White, J. W. C., and Broecker, W. S.: Simulationsof the HDO and $\mathrm{H}_{2}^{18} \mathrm{O}$ atmospheric cycles using the NASA/GISS general circulation model: the seasonal cycle for present-day conditions, J. Geophys. Res., 92, 14739-14760, 1987a.

Jouzel, J., Lorius, C., Petit, J. R., Genthon, C., Barkov, N. I., Kotlyakov, V. M., and Petrov, V. M.: Vostok ice core: a continuous isotope temperature record over the last climatic cycle (160000 years), Nature, 329, 402-408, 1987b.
Jouzel, J., Barkov, N. I., Barnola, J. M., Bender, M., Chappelaz, J., Genthon, C., Kotlyakov, V. M., Lipenkov, V., Lorius, C., Petit, J. R., Raynaud, D., Raisbeck, G., Ritz, C., Sowers, T., Stievenard, M., Yiou, F., and Yiou, P.: Extending the Vostok ice-core record of paleoclimate to the penultimate glacial period, Nature, 364, 407-412, 1993.

Jouzel, J., Lorius, C., Johnsen, S. J., and Grootes, P.: Climate instabilities: Greenland and Antarctic records, C. R. Acad. Sci. Paris, 319, 65-77, 1994.

Jouzel, J., Vaikmae, R., Petit, J. R., Martin, M., Duclos, Y., Stievenard, M., Lorius, C., Toots, M., Mélières, M. A., Burckle, L. H., Barkov, N. I., and Kotlyakov, V. M.: The two-step shape and timing of the last deglaciation in Antarctica, Clim. Dynam., 11, 151$161,1995$.

Jouzel, J., Waelbroeck, C., Malaizé, B., Bender, M., Petit, J. R., Barkov, N. I., Barnola, J. M., King, T., Kotlyakov, V. M., Lipenkov, V., Lorius, C., Raynaud, D., Ritz, C., and Sowers, T.: Climatic interpretation of the recently extended Vostok ice records, Clim. Dynam., 12, 513-521, 1996.

Jouzel, J., Petit, J. R., Souchez, R., Barkov, N. I., Lipenkov, V. Y., Raynaud, D., Stievenard, M., Vassiliev, N. I., Verbeke, V., and Vimeux, F.: Evidence of more than $200 \mathrm{~m}$ thick of lake ice above the subglacial lake Vostok, Central East Antarctica, Science, 286, 2138-2141, 1999.

Jouzel, J., Hoffmann, G., Parrenin, F., and Waelbroeck, C.: Atmospheric oxygen 18 and sealevel changes, Quaternary Sci. Rev., $21,1-3,2002$.

Jouzel, J., Vimeux, F., Caillon, N., Delaygue, G., Hoffmann, G., Masson, V., and Parrenin, F.: Magnitude of the isotope/temperature scaling for interpretation of central Antarctic ice cores, J. Geophys. Res., 108, 4361, doi:10.1029/2002JD002677, 2003.

Jouzel, J., Masson-Delmotte, V., Cattani, O., Dreyfus, G., Falourd, S., Hoffmann, G., Nouet, J., Johnsen, S. J., Leuenberger, M., Oerter, H., Parrenin, F., Raisbeck, G., Schwander, J., Souchez, R., Selmo, E., Stenni, B., Stocker, T., and Werner, M.: Orbital and millenial antarctic climate variability over the last 800000 years, Science, 317, 793-796, doi:10.1126/science.1141038, 2007a.

Jouzel, J., Stiévenard, M., Johnsen, S. J., Fuhrer, K., Landais, A., Masson-Delmotte, V., Sveinbjörnsdottir, A. E., Vimeux, F., and White, J. W. C.: The GRIP deuterium-excess record, Quaternary Sci. Rev., 26, 1-17, 2007b.

Jouzel, J., Lorius, C., and Raynaud, D.: The White Planet, Princeton University Press, 306 pp., 2013.

Kawamura, K., Parrenin, F., Lisiecki, L., Uemura, R., Vimeux, F., Severinghaus, J. P., Hutterli, M. A., Nakazawa, T., Aoki, S., Jouzel, J., Raymo, M. E., Matsumoto, K., Nakata, H., Motoyama, H., Fujita, S., Goto-Azuma, K., Fujii, Y., and Watanabe, O.: Northern Hemisphere forcing of climatic cycles in Antarctica over the past 360000 years, Nature, 912-916, doi:10.1038/nature06015, 2007.

Kawamura, K., Aoki, S., Nakazawa, T., Suzuki, K., and Parrenin, F.: Accurate age scale of the Dome Fuji ice core, Antarctica from $\mathrm{O}_{2} / \mathrm{N}_{2}$ ratio of trapped air, EGU General Assembly Conference Abstracts, Vienna, 14, 8309, 2012.

Koerner, R. M.: Devon Island Ice Cap: core stratigraphy and paleoclimate, Science, 196, 15-18, 1977. 
Koerner, R. M. and Fisher, D. A.: A record of Holocene summer climate from a Canadian High Arctic ice core, Nature, 343, 630631, 1990.

Köhler, P., Fischer, H., and Schmitt, J.: Atmospheric $\delta^{13} \mathrm{CO}_{2}$ and its relation to $p \mathrm{CO}_{2}$ and deep ocean $\delta^{13} \mathrm{C}$ during the late Pleistocene, Paleoceanography, 25, PA1213, doi:10.1029/2008PA001703, 2010.

Krinner, G., Genthon, C., and Jouzel, J.: GCM analysis of local influences on ice core d signals, Geophys. Res. Lett., 24, 28252828, 1997.

Landais, A.: Utility of stable isotopes of $\mathrm{N}$ and Ar as tracers to retrieve past air temperature from air trapped in ice cores, in: Handbook of Environmental Isotope Geochemistry, Springer, 865886, 2011.

Landais, A., Chappellaz, J., Delmotte, M., Jouzel, J., Blunier T., Bourg, C., Caillon, N., Cherrier, S., Malaizé, B., MassonDelmotte, V., Raynaud, D., and Schwander J.: A tentative reconstruction of the last interglacial and glacial inception in Greenland based on new gas measurements in the Greenland Ice Core Project (GRIP) ice core, J. Geophys. Res., 108, 4563, doi:10.1029/2002JD003147, 2003.

Landais, A., Caillon, N., Goujon, C., Grachev, A., Barnola, J. M., Chappellaz, J., Jouzel, J., Masson-Delmotte, V., and Leuenberger, M.: Quantification of rapid temperature change during DO event 12 and phasing with methane inferred from air isotopic measurements, Earth Planet. Sc. Lett., 225, 221-232, 2004a.

Landais, A., Barnola, J.-M., Masson-Delmotte, V., Jouzel, J., Chappellaz, J., Caillon, N., Huber, C., Leuenberger, M., and Johnsen, S. J.: A continuous record of temperature evolution over a whole sequence of Dansgaard-Oeschger during Marine Isotopic Stage 4 (76 to $62 \mathrm{kyr}$ BP), Geophys. Res. Lett., 31, L22211, doi:10.1029/2004GL021193, 2004b.

Landais, A., Steffensen, J. P., Caillon, N., Jouzel, J., MassonDelmotte, V., and Schwander, J.: Evidence for stratigraphic distortion in Greenland Ice Core Project (GRIP) ice core during Event 5e1 (120 kyr BP) from gas isotopes, J. Geophys. Res., 109, D06103, doi:10.1029/2003JD004193, 2004c.

Landais, A., Barnola, J. M., Kawamura, K., Caillon, N., Delmotte, M., Dreyfus, G., Jouzel, J., Masson-Delmotte, V., Minster, B., Freitag, J., Leuenberger, M., Huber, C., Schwander, J., Etheridge, D., Morgan, V., and Van Ommen, T.: Air $\delta^{15} \mathrm{~N}$ in modern firns and glacial-interglacial ice: a model-data mismatch during glacial periods in Antarctica?, Quaternary Sci. Rev., 25, 49-62, 2006.

Landais, A., Barkan, E., and Luz, B.: The record of ${ }^{18} \mathrm{O}$ and ${ }^{17} \mathrm{O}$-excess in ice from Vostok Antarctica during the last 150000 years, Geophys. Res. Lett., 35, L02709, doi:10.1029/2007GL032096, 2008.

Landais, A., Dreyfus, G., Capron, E., Masson-Delmotte, V., Sanchez-Goñi, M. F., Desprat, S., Hoffmann, G., Jouzel, J., Leuenberger, M., and Johnsen, S.: What drives the millennial and orbital variations of $\delta^{18} \mathrm{O}_{\mathrm{atm}}$ ?, Quaternary Sci. Rev., 29, 235246, 2010

Landais, A., Dreyfus, G., Capron, E., Pol, K., Loutre, M. F., Raynaud, D., Lipenkov, V. Y., Arnaud, L., Masson-Delmotte, V., Paillard, D., Jouzel, J., and Leuenberger, M.: Towards orbital dating of the EPICA Dome $\mathrm{C}$ ice core using $\delta \mathrm{O}_{2} / \mathrm{N}_{2}$, Clim. Past, 8, 191-203, doi:10.5194/cp-8-191-2012, 2012.
Lang, C., Leuenberger, M., Schwander, J., and Johnsen, S. J.: $16^{\circ} \mathrm{C}$ rapid temperature variation in central Greenland 70000 years ago, Science, 286, 934-937, 1999.

Langway, C. C.: The history of early polar ice cores, Cold Reg. Sci. Technol., 52, 101-117, 2008.

Langway Jr., C. C.: A 400 meter deep ice core in Greenland, preliminary Report, J. Glaciol., 3, 216-217, 1958.

Lee, J.-E., Fung, I., DePaolo, D. J., and Otto-Bliesner, B.: Water isotopes during the Last Glacial Maximum: new general circulation model calculations, J. Geophys. Res., 113, D19109, doi:10.1029/2008JD009859, 2008.

Lemieux-Dudon, B., Blayo, E., Petit, J.-R., Waelbroeck, C., Svensson, A., Ritz, C., Barnola, J.-M., Narcisi, B. M., and Parrenin, F.: Consistent dating for Antarctic and Greenland ice cores, Quaternary Sci. Rev., 29, 8-20, doi:10.1016/j.quascirev.2009.11.010, 2010.

Leuenberger, M. and Siegenthaler, U.: Ice-age atmospheric concentration of nitrous oxide from an antarctic ice core, Nature, 360 , 449-451, 1992.

Leuenberger, M., Siegenthaler, U., and Langway, C.: Carbon isotope composition of atmospheric $\mathrm{CO}_{2}$ during the last ice age from an Antarctic ice core, Nature, 357, 488-490, 1992.

Lipenkov, V. Y., Raynaud, D., Loutre, M. F., and Duval, P.: On the potential of coupling air content and $\mathrm{O}_{2} / \mathrm{N}_{2}$ from trapped air for establishing an ice core chronology tuned on local insolation, Quaternary Sci. Rev., 30, 3280-3289, 2011.

Lisiecki, L. and Raymo, M.: A Pliocene-Pleistocene stack of 57 globally distributed benthic $\delta^{18} \mathrm{O}$ records, Paleoceanography, 20, PA1003, doi:10.1029/2004PA001071, 2005.

Lorius, C. and Merlivat, L.: Distribution of mean surface stable isotope values in East Antarctica, Observed changes with depth in a coastal area, in: Isotopes and Impurities in Snow and Ice, Proceedings of the Grenoble Symposium, August/September 1975, IAHS, Grenoble, 118, 125-137, 1977.

Lorius, C., Raynaud, D., and Dolle, L.: Ice density and studies of gas taken from a deep levels of an Antarctic Glacier, Tellus, 20, 449-455, 1968.

Lorius, C., Merlivat, L., Jouzel, J., and Pourchet, M.: A 30000 yr isotope climatic record from Antarctic ice, Nature, 280, 644-648, 1979.

Lorius, C., Jouzel, J., Ritz, C., Merlivat, L., Barkov, N. I, Korotkevitch, Y. S. and Kotlyakov, Y. M.: A 150000 year climatic record from Antarctic ice, Nature, 591-596, 1985.

Lorius, C., Jouzel, J., Raynaud, D., Hansen, J., and Le Treut, H.: The ice-core record: climate sensitivity and future greenhouse warming, Nature, 347, 139-145, 1990.

Loulergue, L., Schilt, A., Spahni, R., Masson-Delmotte, V., Blunier, T., Lemieux, B., Barnola, J. M., Raynaud, D., Stocker, T., and Chappelaz, J.: Orbital and millenial-scale features of atmospheric $\mathrm{CH}_{4}$ over the last 800000 years, Nature, 453, 383-386, 2008.

Lourantou, A., Chappellaz, J., Barnola, J. M., Masson-Delmotte, V., and Raynaud, D.: Changes in atmospheric $\mathrm{CO}_{2}$ and its carbon isotopic ratio during the penultimate deglaciation, Quaternary Sci. Rev., 29, 1983-1992, 2010. 
Lüthi, D., Floch, M. L., Bereiter, B., Blunier, T., Barnola, J. M., Siegenthaler, U., Raynaud, D., Jouzel, J., Fischer, H., Kawamura, K., and Stocker, T. F.: High resolution carbon dioxide concentration record 650000-800000 years before present, Nature, 453, 379-382, 2008.

MacFarling Meure, C., Etheridge, D., Trudinger, C., Steele, P., Langenfelds, R., van Ommen, T., Smith, A., and Elkins, J.: Law Dome $\mathrm{CO}_{2}, \mathrm{CH}_{4}$ and $\mathrm{N}_{2} \mathrm{O}$ ice core records extended to 2000 years BP, Geophys. Res. Lett., 33, L14810, doi:10.1029/2006GL026152, 2006.

Malaizé, B., Paillard, D., Jouzel, J., and Raynaud, D.: The Dole effect over the last two glacial-interglacial cycles, J. Geophys. Res., 104, 14199-14208, 1999.

Masson-Delmotte, V., Jouzel, J., Landais, A., Stiévenard, M., Johnsen, S. J., White, J. W. C., Werner, M., Sveinbjörnsdottir, A., and Fuhrer, K.: GRIP deuterium excess reveals rapid and orbital changes of Greenland moisture origin, Science, 309, 118-121, 2005.

Masson-Delmotte, V., Hou, S., Ekaykin, A., Jouzel, J., Aristarain, A., Bernardo, R. T., Bromwich, D., Cattani, O., Delmotte, M., Falourd, S., Frezzotti, M., Gallée, H., Genoni, L., Isaksson, E., Landais, A., Helsen, M. M., Hoffmann, G., Lopez, J., Morgan, V., Motoyama, H., Noone, D., Oerter, H., Petit, J. R., Royer, A., Uemura, R., Schmidt, G. A., Schlosser, E., Simoes, J. C., Steig, E. J., Stenni, B., Stievenard, M., van den Broeke, M. R., van de Wal, R. S. W., van de Berg, W. J., Vimeux, F., and White, J. W. C.: A review of Antarctic surface snow isotopic composition: observations, atmospheric circulation, and isotopic modeling, J. Climate, 21, 3359-3387, doi:10.1175/2007JCLI2139.1, 2008.

Masson-Delmotte, V., Buiron, D., Ekaykin, A., Frezzotti, M., Gallée, H., Jouzel, J., Krinner, G., Landais, A., Motoyama, H., Oerter, H., Pol, K., Pollard, D., Ritz, C., Schlosser, E., Sime, L. C., Sodemann, H., Stenni, B., Uemura, R., and Vimeux, F.: A comparison of the present and last interglacial periods in six Antarctic ice cores, Clim. Past, 7, 397-423, doi:10.5194/cp-7397-2011, 2011.

Meese, D. A., Gow, A. J., Alley, R. B., Zielinski, G. A., Grootes, P. M., Ram, M., Taylor, K. C., Mayewski, P. A., and Bolzan, J. F.: The Greenland Ice Sheet Project 2 depth-age scale: methods and results, J. Geophys. Res., 102, 26411-26423, 1997.

Merlivat, L. and Jouzel, J.: Global climatic interpretation of the deuterium-oxygen 18 relationship for precipitation, J. Geophys. Res., 84, 5029-5033, 1979.

Miller, M. M.: Juneau Icefield Research Project, Alaska, 1950, American Geographical Society, JIRP Report 7, Amer. Geographical Soc., NY, 97 pp., 1954.

Monnin, E., Indermühle, A., Dällenbach, A., Flückiger, J., Stauffer, B., Stocker, T. F., Raynaud, D., and Barnola, J.-M.: Atmospheric $\mathrm{CO}_{2}$ concentrations over the last glacial termination, Science, 291, 112-114, 2001.

Morgan, V. I., Wookey, C. W., Li, J., van Ommen, T. D., Skinner, W., and Fitzpatrick, M. F.: Site information and initial results from deep ice drilling on Law Dome, Antarctica, J. Glaciol., 43, 3-10, 1997.

Morgan, V., Delmotte, M., van Ommen, T., Jouzel, J., Chappellaz, J., Woon, S., Masson-Delmotte, V., and Raynaud, D.: The timing of events in the last deglaciation from a coastal east Antarctic core, Science, 297, 1862-1864, 2002.
Mulvaney, R., Alemany, O., and Possenti, P.: The Berkner Island (Antarctica) ice-core drilling project, Ann. Glaciol., 47, 115124, 2007.

Mulvaney, R., Abram, N. J., Hindmarsh, R. C. A., Arrowsmith, C., Fleet, L., Triest, J., Sime, L. C., Alemany, O., and Foord, S.: Recent Antarctic peninsula warming relative to Holocene climate and ice shelf history, Nature, 489, 141-144, 2012.

NEEM Community Members: Eemian interglacial reconstructed from a Greenland folded ice core, Nature, 493, 489-494, 2013.

Nikolaiev, V. I., Kotlyakov, V. M., and Smirnov, K. E.: Isotope studies of the ice from the Komsolmoskaia station, Antarctica, data of glaciological studies, USSR Acad. Sci., 63, 97-102, 1988.

NorthGRIP community members: High resolution climate record of the Northern Hemisphere back to the last interglacial period, Nature, 431, 147-151, 2004.

Oeschger, H.: The contribution of ice core studies to the understanding of environmental processes, in: Greenland Ice Cores: Geophysics, Geochemistry, and the Environment, Geophysical Monograph 33, AGU, Washington, D.C., 9-17, 1985.

Oeschger, H., Alder, B., and Langway Jr., C. C.: Radiocarbon dating of ice, Earth Planet. Sc. Lett., 1, 49-54, 1966.

Oeschger, H., Alder, B., and Langway Jr., C. C.: An in situ gas extraction system to radiocarbon date glacier ice, USA CRREL Research Report 236, October 1967, J. Glaciol., 6, 939-942, 1967.

Oeschger, H., Beer, J., Siegenthaler, U., Stauffer, B., Dansgaard, W., and Langway, C. C.: Late climate history from ice cores, in: Climate Processes and Climate Sensitivity, edited by: Hansen, J. E. and Takahashi, T., Geophysical Monograph 29, Maurice Ewing vol. 5, AGU, Washington, D.C., 299-306, 1984.

Parrenin, F., Jouzel, J., Waelbroeck, C., Ritz, C., and Barnola, J. M.: Dating the Vostok ice core by an inverse method, J. Geophys. Res., 106, 31837-31851, 2001.

Parrenin, F., Rémy, F., Ritz, C., Siegert, M. J., and Jouzel, J.: New modeling of the Vostok ice flow line and implication for the glaciological chronology of the Vostok ice core, J. Geophys. Res., 109, D20102, doi:10.1029/2004JD004561, 2004.

Parrenin, F., Barnola, J.-M., Beer, J., Blunier, T., Castellano, E., Chappellaz, J., Dreyfus, G., Fischer, H., Fujita, S., Jouzel, J., Kawamura, K., Lemieux-Dudon, B., Loulergue, L., MassonDelmotte, V., Narcisi, B., Petit, J.-R., Raisbeck, G., Raynaud, D., Ruth, U., Schwander, J., Severi, M., Spahni, R., Steffensen, J. P., Svensson, A., Udisti, R., Waelbroeck, C., and Wolff, E.: The EDC3 chronology for the EPICA Dome C ice core, Clim. Past, 3, 485-497, doi:10.5194/cp-3-485-2007, 2007.

Parrenin, F., Masson-Delmotte, V., Kohler, P., Raynaud, D., Paillard, D., Schwander, J., Barbante, C., Landais, A., Wegner, A., and Jouzel, J.: Synchronous change of atmospheric $\mathrm{CO}_{2}$ and Antarctic temperature during the last deglacial warming, Science, 339, 1060-1063, doi:10.1126/science.1226368, 2013.

Paterson, W. S. B., Koerner, R. M., Fisher, D., Johnsen, S. J., Clausen, H. B., Dansgaard, W., Bucher, P., and Oeschger, H.: An oxygen-isotope climatic record from the Devon Island ice cap, Arctic Canada, Nature, 266, 508-511, 1977.

Petit, J. R., White, J. W. C., Young, N. W., Jouzel, J., and Korotkevich, Y. S.: Deuterium excess in recent Antarctic snow, J. Geophys. Res., 96, 5113-5122, 1991. 
Petit, J. R., Jouzel, J., Raynaud, D., Barkov, N. I., Barnola, J. M., Basile, I., Bender, M., Chappellaz, J., Davis, J., Delaygue, G., Delmotte, M., Kotyakov, V. M., Legrand, M., Lipenkov, V. Y., Lorius, C., Pépin, L., Ritz, C., Saltzman, E., and Stievenard, M.: Climate and atmospheric history of the past 420000 years from the Vostok ice core, Antarctica, Nature, 399, 429-436, 1999.

Pol, K., Masson-Delmotte, V., Johnsen, S. J., Jouzel, J., Cattani, O., Durand, G., Falourd, S., Minster, B., Parrenin, F., Ritz, C., SteenLarsen, H. C., and Stenni, B.: New MIS 19 EPICA Dome C high resolution deuterium data: hints for a problematic preservation of climate variability in the "oldest ice", Earth Planet. Sc. Lett., 298, 95-103, 2010.

Raisbeck, G. M., Yiou, F., Fruneau, M., Loiseaux, J. M., Lieuvin, M., Ravel, J. C., and Lorius, C.: Cosmogenic Be-10 concentrations in Antarctic ice during the past 30000 years, Nature, 292, 825-826, 1981.

Raisbeck, G. M., Yiou, F., Cattani, O., and Jouzel, J.: Be-10 evidence for the Matuyama-Brunhes geomagnetic reversal in the EPICA Dome C ice core, Nature, 444, 82-84, 2006.

Raisbeck, G. M., Yiou, F., Jouzel, J., and Stocker, T. F.: Direct north-south synchronization of abrupt climate change record in ice cores using Beryllium 10, Clim. Past, 3, 541-547, doi:10.5194/cp-3-541-2007, 2007.

Ramirez, E., Hoffmann, G., Taupin, J. L., Francou, B., Ribstein, P., Caillon, N., Landais, A., Petit, J. R., Pouyaud, B., Schotterer, U., and Stiévenard, M.: A new Andean deep ice core from the Illimani (6350 m), Bolivia, Earth Planet. Sc. Lett., 212, 337-350, 2003.

Rasmussen, S. O., Andersen, K. K., Svensson, A. M., Steffensen, J. P., Vinther, B. M., Clausen, H. B., Siggaard-Andersen, M.L., Johnsen, S. J., Larsen, L. B., Dahl-Jensen, D., Bigler, M., Rothlisberger, R., Fischer, H., Goto-Azuma, K., Hansson, M. E., and Ruth, U.: A new Greenland ice core chronology for the last glacial termination, J. Geophys. Res., 111, D06102, doi:10.1029/2005JD006079, 2006.

Raynaud, D. and Lorius, C.: Climatic implications of total gas content in ice at Camp Century, Nature, 243, 283-284, 1973.

Raynaud, D., Chappellaz, J., Barnola, J. M., Korotkevich, Y. S., and Lorius, C.: Climatic and CH4-cycle implications of glacialinterglacial $\mathrm{CH}_{4}$ change in the Vostok ice core, Nature, 333, 655657,1988

Raynaud, D., Jouzel, J., Chappellaz, J., Delmas, R. J., and Lorius, C.: The ice record of greenhouse gases, Science, 259, 926-934, 1993.

Raynaud, D., Barnola, J. M., Souchez, R., Lorrain, R., Petit, J. R., Duval, P., and Lipenkov, V. Y.: Palaeoclimatology - the record for marine isotopic stage 11, Nature, 436, 39-40, 2005.

Raynaud, D., Lipenkov, V., Lemieux-Dudon, B., Duval, P., Loutre, M. F., and Lhomme, N.: The local insolation signature of air content in Antarctic ice, a new step toward an absolute dating of ice records, Earth Planet. Sc. Lett., 261, 337-349, 2007.

Reeh, N., Oerter, H., and Thomsen, H. H.: Comparison between Greenland ice-margin and ice-core oxygen-18 records, Ann. Glaciol., 35, 136-144, 2002.

Reeves, C. E., Sturges, W. T., Sturrock, G. A., Preston, K., Oram, D. E., Schwander, J., Mulvaney, R., Barnola, J.-M., and Chappellaz, J.: Trends of halon gases in polar firn air: implications for their emission distributions, Atmos. Chem. Phys., 5, 2055-2064, doi:10.5194/acp-5-2055-2005, 2005.
Risi, C., Bony, S., Vimeux, F., and Jouzel, J.: Water stable isotopes in the LMDZ4 General Circulation Model: model evaluation for present day and past climates and applications to climatic interpretation of tropical isotopic records, J. Geophys. Res., 115, D12118, doi:10.1029/2009JD013255, 2010.

Ruddiman, W. F. and Raymo, M. E.: A methane-based time scale for Vostok ice, Quaternary Sci. Rev., 22, 141-155, 2003.

Salamatin, A. N., Lipenkov, V. Y., Barkov, N. I., Jouzel, J., Petit, J. R., and Raynaud, D.: Ice core age dating and paleothermometer calibration on the basis of isotopes and temperature profiles from deep boreholes at Vostok station (East Antarctica), J. Geophys. Res., 103,8963-8977, 1998.

Schaefer, H., Whiticar, M. J., Brook, E. J., Petrenko, V. V., Ferretti, D. F., and Severinghaus, J. P.: Ice record of $\delta^{13} \mathrm{C}$ for atmospheric $\mathrm{CH}_{4}$ across the Younger-Dryas-Preboreal transition, Science, 313, 1109-1112, 2006.

Schilt, A., Baumgartner, M., Blunier, T., Schwander, J., Spahni, R., Fischer, H., and Stocker, T. F.: Glacial-interglacial and millennial-scale variations in the atmospheric nitrous oxide concentration during the last 800000 years, Quaternary Sci. Rev., 29, 182-192, 2009.

Schmitt, J., Schneider, R., Elsig, J., Leuenberger, D., Lourantou, A., Chappellaz, J., Këhler, P., Joos, F., Stocker, T. F., Leuenberger, M., and Fischer, H.: Carbon isotope constraints on the deglacial $\mathrm{CO}_{2}$ rise from ice cores, Science, 336, 711-714, 2012.

Schwander, J., Sowers, T., Barnola, J. M., Blunier, T., Malaizé, B., and Fuchs, A.: Age scale of the air in the summit ice: implication for glacial-interglacial temperature change, J. Geophys. Res., 102, 19483-19494, 1997.

Schytt, V.: Norwegian-British-Swedish Antarctic Expedition 19491952, Scientific Results 4, Glaciology II, Norsk Polarinstitut, Oslo, Norway, 1958.

Severinghaus, J. P. and Battle, M.: Fractionation of gases in polar ice during bubble close-off: new constraints from firn air $\mathrm{Ne}, \mathrm{Kr}$, and Xe observations, Earth Planet. Sc. Lett., 244, 474-500, 2006.

Severinghaus, J. P. and Brook, E.: Simultaneous tropical-Arctic abrupt climate change at the end of the last glacial period inferred from trapped air in polar ice, Science, 286, 930-934, 1999.

Severinghaus, J. P., Brook, E. J., Sowers, T., and Alley, R. B.: Gaseous thermal diffusion as a gas-phase stratigraphic marker of abrupt warmings in ice core climate records, 157, EOS Supplement AGU Spring meeting, San Francisco, 1996.

Severinghaus, J. P., Sowers, T., Brook, E., Alley, R. B., and Bender, M. L.: Timing of abrupt climate change at the end of the Younger Dryas interval from thermally fractionated gases in polar ice, Nature, 391, 141-146, 1998.

Severinghaus, J. P., Beaudette, R., Headly, M. A., Taylor, K., and Brook, E. J.: Oxygen-18 of $\mathrm{O}_{2}$ records the impact of abrupt climate change on terrestrial biosphere, Science, 324, 1431-1434, 2009.

Severinghaus, J. P., Wolff, E., and Brook, E. J.: Searching for the oldest ice, EOS T. Am. Geophys. Un., 91, 357-368, 2010.

Shackleton, N. J.: The 100000 -year ice-age cycle identified and found to lag temperature, carbon dioxide, and orbital eccentricity, Science, 289, 1897-1902, 2000. 
Siegenthaler, U., Stocker, T. F., Monnin, E., Luthi, D., Schwander, J., Stauffer, B., Raynaud, D., Barnola, J.-M., Fischer, H., Masson-Delmotte, V., and Jouzel, J.: Stable carbon cycleclimate relationship during the Late Pleistocene, Science, 310, 1313-1317, 2005.

Sime, L. C., Tindall, J. C., Wolff, E. W., Connolley, W. M., and Valdes, P. J.: Antarctic isotopic thermometer during a $\mathrm{CO}_{2}$ forced warming event, J. Geophys. Res., 113, D24119, doi:10.1029/2008JD010395, 2008.

Sime, L. C., Wolff, E. W., Oliver, K. I. C., and Tindall, J. C.: Evidence for warmer interglacials in East Antarctic ice cores, Nature, 462, 342-346, doi:10.1038/nature08564, 2009.

Sime, L. C., Risi, C., Tindall, J. C., Sjolte, J., Wolff, E. W., MassonDelmotte, V., and Capron, E.: Warm climate isotopic simulations: what do we learn aboutinterglacial signals in Greenland ice cores?, Quaternary Sci. Rev., 67, 59-80, 2013.

Simonsen, S. B., Johnsen, S. J., Popp, T. J., Vinther, B. M., Gkinis, V., and Steen-Larsen, H. C.: Past surface temperatures at the NorthGRIP drill site from the difference in firn diffusion of water isotopes, Clim. Past, 7, 1327-1335, doi:10.5194/cp-7-13272011, 2011.

Sorge, E.: Glaziologische Untersuchungen in Eismitte (Glaciological research at Eismitte), in: Wissenschaftliche Ergebnisse der Deutschen Groenland Expedition Alfred Wegener 1929 und 1930-31, F. A. Brokaus, Leipzig, Germany, 3, 270 pp., 1935.

Souchez, R. and Jouzel, J.: On the isotopic composition of $\delta \mathrm{D}$ and $\delta^{18} \mathrm{O}$ of water and ice during freezing, J. Glaciol., 30, 369-372, 1984.

Sowers, T.: $\mathrm{N}_{2} \mathrm{O}$ record spanning the penultimate deglaciation from Vostok ice core, J. Geophys. Res., 106, 31903-31914, 2001.

Sowers, T., Bender, M., Raynaud, D., Korotkevich, Y. S., and Orchardo, J.: The delta ${ }^{18} \mathrm{O}$ of atmospheric $\mathrm{O}_{2}$ from air inclusions in the vostok ice core: timing of $\mathrm{CO} 2$ and ice volume changes during the penultimate deglaciation, Paleoceanography, 6, 679696, 1991.

Sowers, T., Alley, R. B., and Jubenville, J.: Ice core records of atmospheric $\mathrm{N}_{2} \mathrm{O}$ covering the last 106000 years, Science, 301, 945-948, 2003.

Spahni, R., Chappellaz, J., Stocker, T. F., Loulergue, L., Hausammann, G., Kawamura, K., Flückiger, J., Schwander, J., Raynaud, D., Masson-Delmotte, V., and Jouzel, J.: Atmospheric methane and nitrous oxide of the late Pleistocene from Antarctic ice cores, Science, 310, 1317-1321, 2005.

Stauffer, B., Fischer, G., Neftel, A., and Oeschger, H.: Increase of atmospheric methane recorded in Antarctic ice core, Science, 229, 1386-1388, 1985.

Stauffer, B., Lochbronner, E., Oeschger, H., and Schwander, J.: Methane concentration in the glacial atmosphere was only half that of the preindustrial holocene, Nature, 332, 812-814, 1988.

Stauffer, B., Blunier, T., Dällenbach, A., Indermühle, A., Scwander, J., Stocker, T. F., Tschumi, J., Chappellaz, J., Raynaud, D., Hammer, C. U., and Clausen, H. B.: Atmospheric $\mathrm{CO}_{2}$ concentration and millennial scale climate change during the last glacial period, Nature, 392, 59-62, doi:10.1038/32133, 1998.
Steffensen, J. P., Andersen, K. K., Bigler, M., Clausen, H. B., DahlJensen, D., Fischer, H., Goto-Azuma, K., Hansson, M., Johnsen, S. J., Jouzel, J., Masson-Delmotte, V., Popp, T., Rasmussen, S. O., Rothlisberger, R., Ruth, U., Stauffer, B., Siggaard-Andersen, M.-L., Sveinbjörnsdóttir, A. E., Svensson, A., and White, J. W. C.: High resolution ice core data show abrupt climate change happens in few years, Science, 321, 680-689, 2008.

Steig, E., Brook, E. J., White, J. W. C., Sucher, C. M., Bender, M. L., Lehman, S. J., Morse, D. L., Waddigton, E. D., and Clow, G. D.: Synchronous climate changes in Antarctica and the North Atlantic, Science, 282, 92-95, 1998.

Stenni, B., Masson, V., Johnsen, S. J., Jouzel, J., Longinelli, A., Monnin, E., Roethlisberger, R., and Selmo, E.: An oceanic cold reversal during the last deglaciation, Science, 293, 2074-2077, 2001.

Stenni, B., Jouzel, J., Masson-Delmotte, V., Röthlisberger, R., Castellano, E., Cattani, O., Falourd, S., Johnsen, S. J., Longinelli, A., Sachs, J. P., Selmo, E., Souchez, R., Steffensen, J. P., and Udisti, R.: A late-glacial high resolution site and source temperature record derived from the EPICA Dome C isotope records (East Antarctica), Earth Planet. Sc. Lett., 217, 183-195, 2003.

Stenni, B., Masson-Delmotte, V., Selmo, E., Oerter, H., Meyer, H., Rothlisberger, R., Jouzel, J., Cattani, O., Falourd, S., Fischer, H., Hoffmann, G., Iacumin, P., Johnsen, S., and Minster, B.: The deuterium excess records of EPICA Dome $\mathrm{C}$ and Dronning Maud Land ice cores (East Antarctica), Quaternary Sci. Rev., 29, 146159, 2010.

Stenni, B., Buiron, D., Frezzotti, M., Albani, S., Barbante, C., Bard, E., Barnola, J. M., Baroni, M., Baumgartner, M., Bonazza, M., Capron, E., Castellano, E., Chappellaz, J., Delmonte, B., Falourd, S., Genoni, L., Iacumin, P., Jouzel, J., Kipfstuhl, S., Landais, A., Lemieux-Dudon, B., Maggi, V., Masson-Delmotte, V., Mazzola, C., Minster, B., Montagnat, M., Mulvaney, R., Narcisi, B., Oerter, H., Parrenin, F., Petit, J. R., Ritz, C., Scarchilli, C., Schilt, A., Schüpbach, S., Schwander, J., Selmo, E., Severi, M., Stocker, T. F., and Udisti, R.: Unified Antarctic and Greenland climate seesaw during the last deglaciation, Nat. Geosci., 4, 46-49, 2011.

Stocker, T. F. and Johnsen, S. J.: A minimum thermodynamic model for the bipolar seesaw, Paleoceanography, 18, 1087, doi:10.1029/2003PA000920, 2003.

Sturges, W. T., Penkett, S. A., Barnola, J. M., Chappellaz, J., Atlas, E., and Stroud, V.: A longterm record of carbonyl sulfide (COS) in two hemispheres from firn air measurements, Geophys. Res. Lett., 28, 4095-4098, 2001a.

Sturges, W. T., McIntyre, H. P., Penkett, S. A., Chappellaz, J., Barnola, J. M., Mulvaney, R., Atlas, E., and Stroud, V.: Methyl bromide, other brominated methanes and methyl iodide in polar firn air, J. Geophys. Res., 106, 1595-1606, 2001 b.

Suwa, M. and Bender, M. L.: Chronology of the Vostok ice core constrained by $\mathrm{O}_{2} / \mathrm{N}_{2}$ ratios of occluded air, and its implication for the Vostok climate records, Quaternary Sci. Rev., 27, 10931106, 2008.

Suwa, M., von Fischer, J. C., Bender, M. L., Landais, A., and Brook, E. J.: Chronology reconstruction for the disturbed bottom section of the GISP2 and the GRIP ice cores: Implications for Termination II in Greenland, J. Geophys. Res., 111, D02101, doi:10.1029/2005JD006032, 2006. 
Svensson, A., Andersen, K. K., Bigler, M., Clausen, H. B., DahlJensen, D., Davies, S. M., Johnsen, S. J., Muscheler, R., Parrenin, F., Rasmussen, S. O., Röthlisberger, R., Seierstad, I., Steffensen, J. P., and Vinther, B. M.: A 60000 year Greenland stratigraphic ice core chronology, Clim. Past, 4, 47-57, doi:10.5194/cp-4-472008, 2008.

Svensson, A., Bigler, M., Blunier, T., Clausen, H. B., Dahl-Jensen, D., Fischer, H., Fujita, S., Goto-Azuma, K., Johnsen, S. J., Kawamura, K., Kipfstuhl, S., Kohno, M., Parrenin, F., Popp, T., Rasmussen, S. O., Schwander, J., Seierstad, I., Severi, M., Steffensen, J. P., Udisti, R., Uemura, R., Vallelonga, P., Vinther, B. M., Wegner, A., Wilhelms, F., and Winstrup, M.: Direct linking of Greenland and Antarctic ice cores at the Toba eruption (74 ka BP), Clim. Past, 9, 749-766, doi:10.5194/cp-9-749-2013, 2013.

Swithinbank, C.: Norwegian-British-Swedish Antarctic Expedition 1949-1952, Scientific Results 3, Glaciology I, Norsk Polarinstitut, Oslo, Norway, 1957.

Taylor, K. C., Hammer, C. U., Alley, R. B., Clausen, H. B., DahlJensen, D., Gow, A. J., Gundestrup, N. S., Kipfstuhl, J., Moore, J. C., and Waddington, E. D.: Electrical conductivity measurements from the GISP2 and GRIP Greenland ice cores, Nature, 366, 549-552, 1993.

Taylor, K. C., White, J. W. C., Severinghaus, J. P., Brook, E. J., Mayewski, P. A., Alley, R. B., Steig, E. J., Spencer, M. K., Meyerson, E., Meese, D. A., Lamorey, G. W., Grachev, A., Gow, A. J., and Barnett, B. A.: Abrupt climate change around $22 \mathrm{ka}$ on the Siple coast of Antarctica, Quaternary Sci. Rev., 23, 7-15, 2004.

Thompson, L. G., Mosley-Thompson, E., Davis, M. E., Bolzan, J. F., Dai, J., Klein, L., Yao, T., Wu, X., Xie, Z., and Gundestrup, N.: Holocene-Late Pleistocene climatic ice core records from Qinghai-Tibetan Plateau, Science, 246, 474-477, 1989.

Thompson, L. G., Mosley-Thompson, E., Davis, M. E., Lin, P.-N., Henderson, K. A., Cole-Dai, J., Bolzan, J. F., and Liu, K.-B.: Late Glacial Stage and Holocene tropical ice core records from Huascaran, Peru, Science, 269, 46-50, 1995.

Thompson, L. G., Yao, T., Davis, M. E., Henderson, K. A., MosleyThompson, E., Lin, P.-N., Beer, J., Synal, H.-A., Cole-Dai, J., and Bolzan, J. F.: Tropical climate instability: the Last Glacial Cycle from a Qinghai-Tibetan ice core, Science, 276, 1821-1825, doi:10.1126/science.276.5320.1821, 1997.

Thompson, L. G., Davis, M. E., Mosley-Thompson, E., Sowers, T. A., Henderson, K. A., Zagorodnov, V. S., Lin, P.-N., Mikhalenko, V. N., Campen, R. K., Bolzan, J. F., Cole-Dai, J., and Francou, B.: A 25000 -year tropical climate history from bolivian ice cores, Science, 282, 1858-1864, 1998.

Ueda, H. T. and Talalay, P. G.: Fifty Years of Soviet and Russian Drilling Activity in Polar and Non-Polar Ice, Report ERDC/CRREL TR-07-20, US Army Engineer Research and Development Center Cold Regions Research and Engineering Laboratory, Hanover, USA, 130 pp., 2007.

Uemura, R., Yoshida, N., Kurita, N., Nakawo, M., and Watanabe, O.: An observation-based method for reconstructing ocean surface changes using a 340000 -year deuterium excess record from the Dome Fuji ice core, Antarctica, Geophys. Res. Lett., 31, L13216, doi:10.1029/2004GL019954, 2004.
Uemura, R., Masson-Delmotte, V., Jouzel, J., Landais, A., Motoyama, H., and Stenni, B.: Ranges of moisture-source temperature estimated from Antarctic ice cores stable isotope records over glacial-interglacial cycles, Clim. Past, 8, 11091125, doi:10.5194/cp-8-1109-2012, 2012.

Vimeux, F., Masson, V., Jouzel, J., Stiévenard, M., and Petit, J. R.: Evidence of a link between deuterium excess in polar snow and ocean conditions over a full glacial-interglacial cycle, Nature, 398, 410-413, 1999.

Vimeux, F., Cuffey, K., and Jouzel, J.: New insights into Southern Hemisphere temperature changes from Vostok ice cores using deuterium excess correction, Earth Planet. Sc. Lett., 203, 829843, 2002.

Vinther, B. M., Buchardt, S. L., Clausen, H. B., Dahl-Jensen, D., Johnsen, S. J., Andersen, K. K., Blunier, T., Rasmussen, S. O., Steffensen, J. P., Svensson, A., Fisher, D. A., Koerner, R. M., Raynaud, D., and Lipenkov, V.: Holocene thinning of the Greenland ice sheet, Nature, 461, 385-388, 2009.

Waelbroeck, C., Jouzel, J., Labeyrie, L., Lorius, C., Labracherie, M., Stiévenard, M., and Barkov, N. I.: Comparing the Vostok ice deuterium record and series from Southern Ocean core MD 88770 over the last two glacial-interglacial cycles, Clim. Dynam., 12, 113-123, 1995.

Waelbroeck, C., Jouzel, J., Parrenin, F., Masson-Delmotte, V., and Genty, D.: Tranferring radiometric dating of the last interglacial sea level high stand to marine and ice core records, Earth Planet. Sc. Lett., 265, 183-194, 2008.

WAIS Divide Project Members: Onset of deglacial warming in West Antarctica driven by local orbital forcing, Nature, 500, 440-444, doi:10.1038/nature12376, 2013.

Watanabe, O., Jouzel, J., Johnsen, S., Parrenin, F., Shoji, H., and Yoshida, N.: Homogeneous climate variability accross East Antarctica over the last three glacial cycles, Nature, 422, 509512, 2003.

Weart, S.: The discovery of global warming, Web hypertext (250 000 words with extensive bibliography and illustrations and more than 2000 hyperlinks), revised annually $2003 \mathrm{http}: / / \mathrm{www}$. aip.org/history/climate, 2008.

Werner, M., Mikolajewicz, U., Heimann, M., and Hoffmann, G.: Borehole versus isotope temperatures on Greenland: seasonality does matter, Geophys. Res. Lett., 27, 723-726, 2000.

Werner, M., Langebroek, P. M., Carlsen, T., Herold, M., and Lohmann, G.: Stable water isotopes in the ECHAM5 general circulation model: toward high-resolution isotope modeling on a global scale, J. Geophys. Res., 116, D15109, doi:10.1029/2011JD015681, 2011.

White, J. W. C., Johnsen, S. J., and Dansgaard, W.: The origin of Arctic precipitation as deduced from its deuterium excess, Ann. Glaciol., 10, 219-220, 1988.

Winkler, R., Landais, A., Sodemann, H., Dümbgen, L., Prié, F., Masson-Delmotte, V., Stenni, B., and Jouzel, J.: Deglaciation records of ${ }^{17} \mathrm{O}$-excess in East Antarctica: reliable reconstruction of oceanic normalized relative humidity from coastal sites, Clim. Past, 8, 1-16, doi:10.5194/cp-8-1-2012, 2012.

Xiao, C., Li, Y., Allison, I., Hou, S., Dreyfus, G., Barnola, J. M., Ren, J., Bian, L., and Kameda, T.: Surface characteristics at Dome A, Antarctica: first measurements and a guide to future ice coring sites, Ann. Glaciol., 48, 82-87, 2008. 
Yao, T., Petit, J. R., Jouzel, J., Lorius, C., and Duval, P.: Climatic record from an ice margin area in East Antarctica, Ann. Glaciogeol., 14, 323-327, 1990.

Yao, T., Thompson, L. G., Mosbrugger, V., Zhang, F., Ma, Y., Luo, T., Xu, B., Yang, X., Joswiak, D. R., Wang, W., Joswiak, M. E., Devkota, L. P., Tayal, S., Jilani, R., and Fayziev, R.: Third Pole Environment (TPE), Environ. Develop., 3, 52-64, 2012.
Zardini, D., Raynaud, D., Scharffe, D., and Seiler, W.: $\mathrm{N}_{2} \mathrm{O}$ measurements of air extracted from Antarctic ice cores: implication on atmospheric $\mathrm{N}_{2} \mathrm{O}$ back to the last glacial-interglacial transition, J. Atmos. Chem., 8, 189-201, 1989. 